\title{
Kalkınma Politikaları Göçe Engel Olabilir mi? Karaman Ermenek İlçe Örneği ${ }^{1}$
}

\author{
DOI: 10.26466/opus.595120
}

\author{
Illknur Ekiz Ataşer* \\ *Araştırma Görevlisi, KTO Karatay Üniversitesi, Sosyal Ve Beşeri Bilimler Fakültesi, Konya/Türkiye \\ E-Posta: ilknr.ekiz@gmail.com \\ ORCID: 0000-0001-5402-2254
}

\section{Öz}

Bu araştırmanın gayesi kalkınmada öncelikli yer olarak geçen Karaman'ın Ermenek ilçesinde barajın yapılması ile birlikte ortaya çıkan bir değişim ve dönüşüm sürecini köy, kasaba ve şehir üçgeninde ortaya koymaktır. Mikrodan makroya kalkınma süreci anlatan bu çalışma baraj yapılan ilçeyi, ilçeye bağlı su altında kalan ve zorunlu göçe tabi tutulan köy halkın ve Konya şehrinde yaşayan Ermeneklileri kapsamaktadır. Son yıllarda Türkiye'de enerji ihtiyacı nedeniyle kalkınmada barajlar öncelikli politika içindedir. Bu anlamda Türkiye'de bir enerji kaynağı olan suyun ne şekilde değerlendirildiği, kullanıldığı ve yapılan barajların nasıl bir katkısı olduğu tartışılmaktadır. İlçede, coğrafi koşullar nedeniyle sanayileşmenin olmaması, tarım alanlarının kısıtlı ve engebeli olması istihdam imkanlarını kısıtlamaktadır. Işse istihdamı geliştirmek, göçü engellemek için Ermenek'in sosyo-ekonomik gelişimini desteklemek adına baraj inşa edildi. Kalkınma eksenli bakıldığında bölge halkı sürdürülebilir bir kazanç elde edemezken, ülke genelinde enerji alanında kazanç elde edilmiştir. Bu kapsamda örneklemimizi oluşturan bölge ve bölge insanının barajla birlikte nasıl bir değiş̧im sürecinden geçtiği değerlendirilmiş, kalkınma politikasinın göçe engel olmadı̆̆̆ tespit edilmiştir.

AnahtarKelimeler: Kalkınma Politikaları, Göç, Toplumsal Değiş̧im, Baraj.

\footnotetext{
${ }^{1}$ Bu çalışma Selçuk Üniversitesi, Sosyal Bilimler Enstitüsü Sosyoloji Ana Bilim Dalında bitirilen "Suyun Metalaşması: Ermenek'te Ekonomik VeToplumsal Dönüşüm” isimli yüksek lisans tezine dayanmakta olup, 2013 yılındaTürkiye Lisansüstü çalışmalar kongresinde bildiri olarak sunulmuştur.
} 


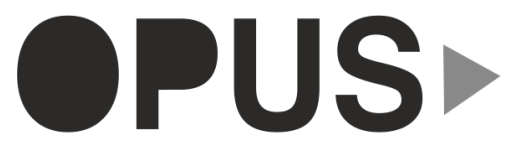

Uluslararası Toplum Araştırmaları Dergisi International Journal of Society Researches
E-ISSN : 2528-9535

YIl Year: 9

Cilt Volume: 14

Sayı Issue :20

Aralık December 2019

Makalenin Gelis Tarihi Received Date: 22/07/2019 Makalenin Kabul Tarihi Accepted Date: 08/12/2019

\title{
Can Development Policies Prevent Migration? The Case of Ermenek Sub Province of Karaman
}

*

\begin{abstract}
The purpose of this study is explain the social transformation experienced in Ermenek sub province of Karaman following the construction of a hydroelectric dam. This attempt is being made on the basis of a triangle formed by the village, town, and city. Using a perspective encompassing micro and macro levels of social transformation, this study is conducted with village communities who were subjected to compulsory migration as their villages submerged in the dam lake and those who migrated from Ermenek to the city of Konya. In recent years, dams have an important place in developmental projects of Turkey due to the increased need for energy. In this context, the ways in which water is used as energy resource, as well as the social impact of the dams built is discussed. Due to geographical conditions, industrialization is low and agricultural lands scarce, hence the low employment opportunities. In order to prevent work and employment motivated migration from the sub province, a dam has been built in Ermenek to support socio-economic development. In terms of developmental principles, the dam fails to provide a sustainable source of income for village communities, while the electricity produced is vital for the country. Consequently, my research on the region and its current and former inhabitants reveal that the dam as a developmental project has failed to prevent emigration from Ermenek.
\end{abstract}

Keywords: Developmental Projects, Emigration, Social Transformation, Dam. 


\section{Giriş}

Türkiye son yıllarda hızlı bir değişim dönüşüm geçirmekte olup kentsel olduğu kadar kırsal alanlarda da demografik, sosyo-ekonomik, siyasi ve toplumsal yapı olarak değişim yaşamaktadır. Baraj yapılan pek çok bölgede değişim yaşandı. Bunlardan biri de Ermenek ilçesi olup, son yılların en hızlı değişim yaşayan yerlerden biri oldu. Birçok yere göre su rezervi çok olan ilçe, Türkiye'de elektrik santrali kurulan ve elektriğe ulaşan ilk yerlerden olmuştur. 2000 yıllarına gelindiğinde ilçe sahip olduğu su havzası ile gündeme alınarak kalkınma için politika konusu olmuştur. Genel olarak ilçenin değişimi incelendiğinde tarihsel olarak nüfus, ulaşım ve neoliberal politika boyutlarıyla öne çıkmaktadır.

Teknolojinin kıra girmesi, insan emeğine olan ihtiyacın azalması, Türkiye'nin sosyo-ekonomik yapısını değiştirerek nüfus yapısını bozmuştur. 1950'lere kadar kentte ve köyde yaşayan nüfus değişken değil istikrarlı şekilde gitmekteydi. Fakat 1950'lerden sonra Türkiye'de uygulanan politikalar nüfusun dengesini değiştirmiştir. Bu süreçte kent nüfusu artmaya kır nüfusu düşmeye başlamıştır. Tarımdan kopuş başlamış tarım dışı alanlara doğru nüfus kaymaya başlamıştır. Kır nüfusunun azalması ve kent nüfusunun artması Türkiye' de sosyo-ekonomik yapıyı da değiştirmiştir. Özellikle "ekonomik ilişkilerin değişmesi yeni tip sosyal bağların doğmasına sebep olmuş, köylüler, köy topluluğu içinde fazla bir direnmeyle karşılaşmadan, şehir adetlerini ve kıyafetlerini kendiliklerinden kabul etmeye istekli görünmüşlerdir. Küçük köyler de birbirleriyle birleşerek veya daha büyük köylerin bir parçası haline gelerek ortadan kalkma yoluna girmişlerdir. Bununla beraber köylülerin, hayat şartlarından doğan görüş ve istekleri, siyasette ifadesini bulacak ve bu görüş ve istekler partiler tarafından ele alınarak günlük siyaset çerçevesi içinde etkisini göstermiştir"(Karpat, 2010, s.197-98).

Kırsal alandaki en büyük değişim dinamiğini getiren parametre ise ulaşım olmuştur. “Demiryollarının, limanların yapılışı ile dışa bağlanan tarımsal ekonomi, tütün, pamuk gibi bazı endüstriyel bitkilerin üretiminin artmasına yol açmıştır. Fakat cumhuriyet dönemine değin Türk köyü pazar için üretim yapan, örgütlenmiş ve modern çiftçiliğe geçmiş bir birim değildi. Bu nedenle köy, bir komün ekonomisinin niteliklerine sahip ol- 
madığı gibi, yerel özerkliğe, zengin akçal kaynaklara da sahip değildi"(Geray, 2011, s.25). Ulaşımla birlikte hem eğitim alanında hem sağlık hem altyapı ve girdi kullanımlarında değişim yaşanmıştır. Bunun sonucunda da aile kurumunda birtakım değişimler yaşanmaya başlamış, bütünüyle kırsalda toplumsal değişim başlamıştır. "Şehir ile köy arasında bağlantı sıkılaştıkça, köyün şehirle bütünleşmesi ilerledikçe köy daha çok dışa açılır, daha çok dışa bağımlı olur. Tarımdan ayrılan zanaatların şehirde sanayiye dönüşmesine koşut olarak köy tarımsal üretimde uzmanlaşır. Üretim çiftçinin öz ihtiyaçlarını aşan miktarlarda yapılmaya başlar hatta pazardaki kimliği belirsiz tüketicinin ihtiyaçları tamamıla tarımsal üretimin amacı haline gelir. Tarım işletmeleri pazar için çalışan, üründe uzmanlaşmış çağdaş teknolojiyi kullanan muhasebe esaslarına uyan işletmelere dönüşür. Şehirde ve köyde görülen bu değişmeler, köydeki yaşama biçimini de etkiler. Köydeki yaşama biçimi şehirli özellikleriyle donanırken kendi geleneksel niteliklerini yitirir ve kapitalist topluma geçiş süreci içinde köy şehirleşir. Şehir köyü eriterek yavaş yavaş ortadan kaldırır"'(Güçbilmez, 1972, s.3).

1980 sonrası hem ekonomi hem siyasi açıdan radikal politikalar hızlanmış, neoliberal zihniyet bütünüyle devlet politikası haline gelince iç pazardan ziyade dış pazara dolayısıyla küresel bir pazara entegre olma çabası yaşanmıştır. "Hem ABD ve Avrupa Birliği'nin hem de kalkınmacı devletlerin, iç pazara yönelik korumacı önlemlerden vazgeçmesi gündeme geldi. Bu projeye göre tarım ürünlerinde ticaret artacak; ithalatın s1nırlandırılması, tarımsal ürün fiyatlarının yüksek tutulması ve üreticilerin çeşitli girdi sübvansiyonlarıyla desteklenme politikaları terk edilecekti. Yani tarımda küçük üretici bir yandan ticaretin serbestleşmesi, bir yandan da sermayenin tarıma nüfuz etmesiyle piyasanın çalkantısıyla karşı karşıya gelecekti”(Keyder ve Yenal, 2013, s. 37). Özellikle “Türkiye gibi mali imkânları kısıtlı ve uluslararası kuruluşların baskılarına direnç gösterememiş ülkelerde, piyasa aktörlerini ve önceliklerini merkezine alan iktisadi ve siyasi dönüşüm görece daha süratli ve yoğun yaşandı. 1980 sonrası döneme damgasını vuran çeşitli yasal ve siyasi değişikliklerle ulusal kalkınmacı dönem boyunca tarım ve gıda sektöründe kademeli bir şekilde oluşmuş düzenleme rejimi ve bu rejimi belirleyen temel ilkeler ve siyasalar ya kabuk değiştirdi ya da yürürlükten kalktı"(Keyder ve Yenal, 2013, s.49-50). 
“Özellikle son yıllarda devletin ve kimi şirketlerin kırsal bölgelerdeki enerji, turizm ve madencilik yatırımları bu süreci hem hızlandırıyor hem de derinleştiriyor. Dünyada başka yerlerde olduğu gibi, meralar, otlaklar, ormanlar ve nehirler süratle "ortak kaynak" olma özelliklerini kaybediyor ve özelleştiriliyor. Hemen hemen her bölgede barınma, beslenme, 1sınma, sulama, hayvan otlatma gibi hem yaşama hem de üretme anlamında köylülerin çok önemli ihtiyaçlarını ortak doğal kaynaklar madencilik, enerji, turizm şirketlerinin eline geçiyor"(Keyder ve Yenal, 2013, s.45-46).

Bahattin Akşit ve Çağlar Keyder 1980'li yılların başında yaptıkları farklı köy araştırmalarında, Türkiye'de kırsal bölgelerin dönüşümünde bölgesel farklılıklara dikkat çekmektedir. "Bunun önemli bir nedeni pazarın farklı bölgelere farklı zamanlarda nüfuz etmiş olmasıdır. Karadeniz bölgesinin sahil şeridinin bazı bölgeleriyle birlikte Akdeniz ve Ege kıyıları nispeten daha erken bir dönemde pazarla bütünleşmiş ve buralardaki köylüler küçük meta üreticilerine dönüşmüştür. İç bölgelerdeki köylerde de 1960'lardaki ekonomik büyüme ve teknolojik kazanımların ardından ulusal pazar için genelde tahıl üreten çiftçiler olmuşlardır. Doğu ve Güneydoğu Anadolu bölgelerinde, kırdaki hanelerin sosyo-ekonomik açıdan hayatta kalması giderek imkânsız hale geldiği günümüze kadar daha ziyade içe kapalı geleneksel köylülük koşulları hüküm sürmüştür"(Keyder ve Yenal, 2013, s.53).

1990-1994 dönemi altıncı beş yıllık kalkınma planında ise, "kırsal alana ilişkin olarak; bu alanda mahalli hizmetlerin verimliliğini artırmak için ilçe özel idarelerinin kurulacağı, küçük belediyeler ve köy idarelerinin güçlendirilmesi yönünde hazırlık çalışmalarının sonuçlandırılacağı, kırsal kesime dinamizm kazandırmak amacıyla 'kırsal alan planlama' yaklaşımı çerçevesinde hizmetlerin ve tarıma dayalı sanayi yatırımlarının merkez köy ve kasabalara yönlendirilmesinin destekleneceği ifade edilmiştir" (Bakırc1, 2007, s.179).

“Bu dönemde kırsal alan göstergelerinde de önemli değişimler yaşanmıştır. 1990 yılında yapılan sayıma göre kırsal nüfus \%41'lik oranla ağırlığını önemli ölçüde kaybetmeye başlamış ve bir önceki döneme göre (1980'de \%56) oransal olarak büyük bir azalış göstermiştir. Bu değişim tarımsal istihdamda da belirgin olarak ortaya çıkmış, 1980' de \%54 olan tarımsal istihdam 1990 'da \%48'e gerilemiştir. Belirtilen dönemde tarımın GSMH'daki payı da \%16'ya düşmüştür"(Bakırc1, 2007, s.181).1996-2000 
dönemi yedinci planda ise küreselleşme ve dişarıya entegre olma dikkati çekmektedir. Bu dönemde kırsal sanayi kavramı kullanılmaya başlanmış ve toprak-su kaynakları beraber planlama dâhilinde yapılmaya başlanmıştır. "Toprak ve su kaynaklarının kullanımının planlaması ile yönetimi konusunda ülke genelinde belirlenmiş kapsamlı bir politika bulunmadığı, toprak ve su kaynakları potansiyelinin tespitine ilişkin veri toplama, etüd ve araştırma çalışmalarına yeterince önem verilmediği, sınırlı olan toprak ve su kaynaklarının tahsis, kullanım ve yönetimine yönelik yeterli mevzuatın bulunmamasının doğal ve ekonomik kaynakların israfına yol açtığ belirtilmiştir "(Bakırc1, 2007, s.185).

2001-2005 arası sekizinci beş yıllık kalkınma planında ise yine toprak ve su kaynaklarına olan vurgu dikkat çekmektedir. "Kırsal altyapının oluşturulması kapsamında; toprak ve su kaynaklarının geliştirilmesine yönelik tarımsal altyapının yaygınlaştırılması, kaynakların yönetimi ve etkin kullanımına dair çalışmaların yapılmasının önemini korumakta olduğu, bu nedenle kırsal altyapı hizmetlerinin yaygınlaştırılması ve etkinliğinin artırılmasında merkezi kamu kuruluşları, yerel yönetimler ve sivil toplum örgütlerinin eşgüdüm içinde çalışmalarının sağlanacağı ifade edilmiştir" (Bakırc1, 2007, s.202).

2007-2013 dönemini oluşturan dokuzuncu kalkınma planı ise ilk defa yedi yıllık olmak üzere hazırlanmıştır. Bu planda "tarımsal ve kırsal kalkınma faaliyetleri konusunda geleceğe yönelik beklenti ve perspektifler üzerinde de durulmakta, Tarımsal Yapının Etkinleştirilmesiyle ilgili olarak; gıda güvencesinin ve güvenliğinin sağlanması ile doğal kaynakların sürdürülebilir kullanımı gözetilerek, örgütlü ve rekabet gücü yüksek bir tarımsal yapı oluşturulacağı, üretimin talebe uygun olarak yönlendirilmesini sağlayacak politika araçları uygulanırken, Türkiye'nin AB'ye üyeliği sonrasında birlik içinde rekabet edebilmesi için tarımsal yapıda gerekli dönüşüme öncelik verileceği ileri sürülmektedir" (Bakırcı, 2007, s.270).

"Günümüzdeki "tarım sektörünü" toprak sahipliği, tarımsal sermaye ve emek üçgeni etrafında ortaya çıkan toplumsal ilişkilerden ve farklı ölçeklerde tarımsal işletmelerden ibaret bir toplam olarak göremeyiz. Girdileri, çıktıları, sermayesi ve emeğiyle, tarım artık bütünleşmiş ve karmaşık bir kapitalist dünya ekonomisinin bütünsel bir parçası olmuştur"(Keyder ve Yenal, 2013, s.38). Bu bütünleşme ise tarım sektörüne belirsizlik ve gü- 
vensizlik duygusunu getirmiştir. Devlet desteğinin çekilmesi, piyasaya liberal ve neoliberal politikaların hâkim olması kırsalı boşluğa düşürmüş, serbest piyasanın zorlu koşulları altında tek başına bırakılmıştır. Neoliberal politikaların her gün ne getireceği bilinememekte dolayısıyla güvensizlik duygusu yaşanmaktadır. Bu belirsizlik ve güvensizlik bütün dünyaya yayılmakta ve tarımsal yapılar bozulmaktadır." Gelişmiş ülkelerde dâhil tarımsal işgücü hem mutlak olarak azalmakta, hem de oransal olarak azalmaktadır. Özellikle gelişmekte olan ülkelerde olduğu gibi ülkemizde de tarım kesimindeki işgücünü diğer sektörlere iten diğer dinamiklere bakıldığında bunların, kırsal kesimdeki nüfusun baskısı, toprak dağılımındaki dengesizlik, gizli işsizlik, eksik istihdam, yoksulluk, mekanizasyon düzeyinin artışı, sosyal olanakların ve altyapının yetersizliği ile kentsel yaşamın çekiciliğinden ileri geldiği ortaya çıkmaktadır" (Yıldırak ve Gülçubuk, 1994, s.851).

Diğer yandan günümüzde köy ve tarım, genelde ise kır, gıda alanı üzerinden daha çok konuşulur duruma gelmiş, özellikle GDO ve doğal beslenme etrafında bir kıra bakış gelişmektedir. Ve bu bakış açısıyla köy "şimdilerde yüksek ekonomik ve kültürel sermayeye sahip toplumsal s1nıflarda ve zayıflama rejimi yapanların gündelik hayatında beslenme üzerinden prim"(Özensel, 2013, s.35) yapmaktadır. Sadece yemek alanında değil gezi-inceleme alanında da programlar yapılmakta ve bunun üzerinden köylülüğün biteceği tezleri konuşulmaktadır. Bunun dişında hala k1rın değişen yapısı, değerleri, emeği ve parçalanmışlı̆̆ı, toprak yoksunluğu hatta yerin yurdun eksikliği, küresel pazarın altında, küresel baz da projeler yapılmasıyla devam etmektedir.

"Kalkınma-gelişme ve sonucunda büyüme" sözcügü aynı anlama gelmemektedir. Kalkınma kavramı "az gelişmiş ülkelerin insanlık tarihinde daha önce hiçbir uygarlığın başaramadığı bir şeyi başarmış olan batıyı izlemesi; piyasa sistemini temel esas kabul ederek sermaye, sanayi ve teknoloji konusunda batılı standartları yakalamak için gelenekselden moderne geçiş yapması; bu geçişin iktizası olarak, davranış kalıplarını ve yaşam tarzını geliştirmesi" şeklinde izah edile gelmektedir (Polat, 2004, s.64).

“Türkiye'de 1950'lerden bu yana belli aralıklarla kongreler düzenlenmiş, yıldan yıla bir enerji bunalımı süreci ortaya çıktığı ve bunun için doğal kaynakların araştırılması yönünde faaliyetlere geçildiği görülmüştür. 
Daha çok nükleer alanda çalışmaların yapılmasının yanında hidrolik ve termik santraller öne çıkmıştır. Bu nedenle kaynağı doğal kaynak olan yeni sermaye biçimi ortaya çıkmıs, doğa temelli bir ekonomiye doğru gidilmeye başlanmıştır. 1994 yıllarına gelindiğinde ise kongreler de enerji çalışmaları daha da genişletilmiş, her türlü doğal kaynak değerlendirilmeye alınmış, ar-ge çalışmaları yoğunlaştırılmış ve özelleştirmede adımlar atılmaya başlanmasına dair sunumlar yapılmıştır. 2000'li yıllara doğru ise özelleştirme, serbestleştirmeler artmış yeni stratejiler geliştirilmiştir" (Ekiz, 2013 s.237).

1990'lardan sonra neoliberalizmin kalkınma ve yoksulluk sorununu çözmesinde yetersiz olduğu anlaşılmış ve kalkınma sorunu doğanın sömürülmesi ve artı değere el konulması bağlamında ele alınmaya başlanmıştır. (Öztürk, 2014, s.15). “Suyun metalaşmasında, biri, suyun kendisinin nihai bir kullanım değeri, bir ürün olarak piyasada alınıp satılabildiği; diğeri ise suyun başka metaların üretim süreçlerine meta formunu almış bir hammadde olarak katıldığı birbiriyle özdeş fakat farklı iki durum söz konusudur" (Y1lmaz, 2009, s.83). Suyun bir 'hak' değil 'ihtiyaç' olarak tanımlanması suyun metalaşması ve özelleştirilmesini meşrulaştırmaktadir" (Kartal, 2009, s.67).

Doğanın meta haline gelmesinde "kapitalistler sadece karı amaçlamakta ve aldıkları kararların sonuçlarını görmezlikten gelmektedirler: büyük şirketler tropik ormanların aşırı kesilmesinden büyük karlar sağlamakta ama bunun biyolojik çeşitlilik ve iklim dengesi üzerindeki olumsuz sonuçlarına aldırmamakta ve ileri ülkelere dayatılan aşırı tüketim modeli gezegendeki hammaddeler ve enerji kaynakları üzerinde büyük baskı yaratmakta ve gezegen ölçeğinde kapitalist gelişmenin sonucu olan azgelişmiş ülkelerdeki yoksulluk, doğanın üretici gücünün tahribini hızlandırmaktadır"(Gouverneur, 1997, s.214-15). Bu durumsa neoliberalizmin her alandaki eziciliğinden sadece biridir.

Türkiye'de ise suya el konulması "suyun metalaşması, bir yandan sermaye birikiminin bir başka ihtiyacını sağlarken, bir yandan da yenilenebilir enerji ihtiyacının karşılanmasına hizmet edecektir. Metalaşma sürecinin bir gereği olan 'spesifik bir su arzının oluşturulması' suyun belli rezervuar ve barajlarda toplanması anlamına geldiği ölçüde, suyun metalaşması enerji şirketlerinin de ilgi odağı haline gelmiş durumdadır"(Yılmaz, 2009, s.276-277). Aynı zamanda bu sosyal ve ekonomik politikalar 
gereğince yapılanların kalkınma sağlayacağı, bölgeleri geliştireceği söylemleri kamuda sıkça da yer almaktadır.

Burada "hak-temelli söylemlerle, ekonomik gelişme ve sürdürülebilir kalkınma programları arasında bir çelişki görülmektedir. Hükümetlerin genel eğilimi neo-liberal siyasi ve ekonomik ajandanın su konusunda uygulanmaya çalışılmasıdır. Bu da, sübvansiyonların kaldırılması, özelleştirme, metalaştırma ve yönetimin desantralizasyonudur. Yakın zamana kadar su sunumu ve yönetiminde, kaynak yöneticisi, servis sunucu ve düzenleyici olarak tek aktör kamu sektörüyken, şimdi, neo-liberal pazar ideolojilerinin etkisiyle, pek çok ülkede su altyapısında yatırım ve tahsis aşamalarında özel sektörün, hükümetlerle ortaklıklar biçiminde ya da tek başına yer alması alternatif bir politika olarak görülmektedir. Politikadaki bu dönüşüm devletlerin özerk kararları gibi görünse de, uluslararası finans kuruluşları özel sektöre daha fazla yer verilmesi konusunda baskı yapmaktadırlar. Su sektöründe kamu ve özel sektörün rollerinin yeniden belirlenmesine yönelik müzakereler Dünya Ticaret Örgütü (WTO) ve onun Hizmetlerin Mübadelesine İlişkin Genel Anlaşması (GATS) çerçevesinde sürmektedir (12)" ( Kartal, 2009, s.68).

Kapitalizmin etkin olarak faaliyet gösterdiği ve içli dışlı olduğu alanlardan biri doğadır. Zaten kapitalizm özü gereği doğayla beraber ilişki içerisindedir fakat özel olarak kasten doğa ile bir ilişki kurma biçimini de gösterir. Bu son zamanlarda zorunluluk kazanmış bizzat doğa, üretim amaçlı ve kar getirecek şekilde kullanılmaktadır. Bizzat doğa metalaşma sürecine girmiş ve doğadaki pek çok şey metalaştırılmıştır. Bu metalaşma etkin ve üretken doğayı geri dönülemeyecek şekilde, insanlığın büyük atılımlar yapması sonucu farklı bakış açılarıyla tahribata uğratmıştır. "İnsanlığın kökeninde bulunan bir gerçeklik ve yaşam kaynağ baskı altına alınarak yitirilen, daha sonra yeniden bulunarak özgürleştirilen ve bu yüzden de belirsiz bir geçmişle idealleştirilmiş bir gelecek arasına yerleştirilen Doğa'nın XVIII. yüzyılda bir güç kaynağı olarak keşfedilmesiyle birlikte, bu kural her yerde geçerli olacaktır. Gerçekliğin yükselişiyse olayın diğer yüzü yani Doğa'nın tekniğin egemenliği altına girmiş olduğu evredir" ( Baudrillard, 1998, s.48).

Hem baskı hem özgürleştirme gibi iki uçlu çizgi arasında gidip gelen doğa bütün dengesini kaybetmiş ve insanlığın elinde hoyratça kullanılarak hırpalanmıştır. “Toprakta yaratıcı yıkımın upuzun tarihi, bazen 
"ikinci doğa" denen şeyi, yani insan eylemiyle yeniden biçimlenmiş olan doğayı üretmiştir. İnsanların yeryüzünde yaşamaya başlamasından önce var olmuş olan "ilk doğa" dan bugün pek az şey kalmıştır, belki de hiçbir şey. Yeryüzünün en ücra köşelerinde, yaşanması en zor olan yerlerde bile insan etkisinin izlerine rastlanır. Kapitalizmin yükselişinin damgasını vurduğu son üç yüz yıl boyunca toprakta yaratıcı yıkımın hızı ve yaygınlığı muazzam biçimde artmıştır" (Harvey, 2012, s.191-2). Bu yıkıcılığın bugün uygulanan neoliberal politikalarla farklı bir boyut almış olması ve hızla ilerlemesi dikkat çekmektedir. “Üçüncü dünya'da ya da Doğu ülkelerinde, kalkınmanın getirdiği zorunluluklar çevre sorunlarını ikinci plana atmaktadır. Burada bir muamma gizlidir. Çünkü yalnızca kapitalist verimliliğin mantığına kapılmış ya da tekniğin dünyasını yönettiği düşünülen bilimci ideolojiyle körleşmiş olmak şöyle dursun, liberal demokrasilerimiz özeleştirilerine en radikal biçimleri de dâhil olmak üzere, bizzat yol vermektedirler"'(Ferry, 2000, s.27).

Toprağın parayla mübadelesi ortaya yeni bir ilişki çıkarır. “Toprağın bireysel tahsisi sayesinde yalnızca kollarının gücüne sahip olabilen insanlar varolabiliyor... Bir insanı boşluğa koyduğunuzda, onun havasını soymuş olursunuz. Toprağı ondan aldığınızda da aynı şeyi yapmış olursunuz... Çünkü böylece o kişiyi zenginlikten yoksun bir mekâna koymuş ve böylece onu sizin arzularınıza boyun eğmek dışında her türlü yaşama yolundan mahrum birakmış oluyorsunuz" demektedir ( Foster, 2001, s.231).

Türkiye' de suya bakış açısı farklılıklar göstermektedir. Kimileri suyun bir hak olduğunu söylerken kimileri suya kıt ve ihtiyaç temelli bakmaktadır. Bu yüzden suyun kendi haline bırakılmaması gerektiğini, bunun değerlendirilmesi yani suyun kendi halinde akışına bırakılmaması gerektiğini söylemektedir. Şu an ki mevcut yöneticiler bu ikinci görüşü savunmaktalar ve bu yönde politikalar yapmaktadırlar. Savunmaları tarımsal sulama ve enerji ihtiyacının karşılanması için bunun gerekli olduğunu söylemektedirler. Bu nedenle Türkiye' de son yillarda artan baraj projeleri tamamen suyu hem kontrol altına almak, kendi söylemleriyle dışarıya bağlı olunan enerjide bağımlılıktan kurtulmak hem de kar sağlamaktır.

Nihayetinde Türkiye' deki süreç dönemler itibariyle analiz edildiğinde, 1970 öncesinde kamu kurumları, özel imtiyazlar ve dağınık uygulamalarla birlikte yatırımın, üretimin sınırlı olduğu, hidroelektrik enerji üretim potansiyelinin toplam elektrik enerjisi potansiyeli içindeki payı yüzde 
35'ler düzeyinde kalmıştır. İktisadi kriz ve darbe dönemlerinde de 19821984 yılları arasında özel sektörün yatırım yapmadığı, kamu tekelinin hâkim olduğu görülür. 1984-2001 döneminde ise sektörün özel kesime aç1lımı için yasal düzenlemeler yapılmış, Yİ (yap-işlet), YİD (yap-işlet-devret) modellerine işlerlik kazandırılmıştır (Yılmaz, 2009, s.349). 2001'den beride bu düzenlemeler genişletilmiş, dişarıya dönük ortaklıklar, yabancı şirketlerle iş birliği yapma konusunda ilerlemiştir. Bu on yıl içinde 206 baraj yapılması da bunu göstermektedir.

\section{Ermenek İlçesine Kısa Bir Bakış}

Ermenek ilçesi Boran'ın anlattığı köy yapısı ile aynı şekli göstermektedir: "Köy adeta ikiye bölünmüştür; yukarıda dağlarda köyün kendisi, aşağıda ovada ise yazın göçtükleri saha. Bu orta tip köylere 'sınır' veya 'geçiş' köyleri de denebilir. İktisadi bakımdan olduğu kadar sosyal bakımdan da bu köyler iki esas tipin arasında olan köylerdir. Bunlar ayn zamanda 'geçiş' halinde köylerdir. Ova tipindeki köy şartları ovadan dağ eteklerine doğru yayılıyor, gittikçe bu köyler ova köylerine benziyorlar; ova ile kasaba ile münasebetleri artıyor" (Boran, 1945, s.23). İlçe asıl olarak dağ eteklerinde kurulmuş, daha sonra yazları aşağı ovaya, Göksu vadisine yakın yerlere göç eder olmuşlardır.

Bahattin Akşit küçük toprak mülkiyetine sahip köy türlerini de ikiye ayırır ve Ermenek kasabasını da şöyle belirtir:“Birinciler, pazar için geniş çapta üretim yapamayıp kendi için üretim yapan köyler ikinciler ise pamuk gibi endüstriyel bitki üreten köylerdir. Birinci tür köylere Ermenek'te rastlarız. Antalya çevresinde araştırma yaparken araştırma yaptığım köylere Ermenek'ten küme küme işçilerin geldiğini öğrenmiştim. Ermenek'e gidişimiz bunun nedenlerini araştırma olanağı verdi. Ermenek köyleri her yanı dağlarla çevrilmiş olan Göksu ırmağının çıtığı yerde kurulmuşlardır. Ekilir ve toprak alanları çok dardır ve yaya yüründüğünde her yarım ya da bir saatte yeni bir köye rastlanmaktadır. Bu bölge diğer kasaba ve şehir pazarlarına çok uzak olup yeni yapılan ve uçurumlardan geçen bir yolla dişarıya bağlanmıştır. Bölgede birkaç tane pazar kuruluyorsa da bunlar ancak yazın üç ay gibi kısa bir süre için işliyorlar. Bu yüzden Pazar için üretim çok ilkel, henüz köylerde pulluk bile yayılmamış. Kendi içinde 
üretimde pek yeterli değil, çünkü hızlı nüfus artışının sonucu toprak alabildiğine bölüşülüp ufalanmış. Şimdiki durumda her köyün aşağ1 yukarı yüzde doksana yakını köyün yüzde onundan ve pazarlardan satın alarak geçiniyor (Akşit, 1966, s.66-67).

Ermenek'te sanayi alanında da üretim yoktur. Hem coğrafi yapısı buna izin vermemiştir. Buna bağlı olarakta üretim yapılabilen alanlarda da az kişi istihdam bulabilmektedir. "Ermenek ilçesinde; Karaman Ticaret ve Sanayi Odası'na kayıtlı olarak faaliyet gösteren 128 üye bulunmaktadır. Bu üyelerin sayılarına göre dağılımına bakıldığı zaman Perakende Ticaret (32), Kömür ve Linyit Çıkartılması (19), Kara Taşımacılığı ve Boru Hattı Taşımacılığ (14) ve Diğer Madencilik ve Taş Ocakçılığı (10) faaliyetlerinde yoğunlaşma görülmektedir. Ayrıca, Ermenek ilçesinde 2 adet esnaf ve sanatkârlar odası bulunmakta, bu odalara kayıtlı toplam 1.142 adet esnaf ilçede faaliyet göstermektedir"(Mevka, 2011, s.17).

Türkiye'de bugün değişimin dinamiklerine baktığımızda da özellikle yerel bölgeler açısından ilk sırayı "barajlar" almaktadır. Yani "su" değişimin temel dinamiği olmakta, su kaynaklarıyla zengin olan yerlere barajlar yapılmaktadır. Su kaynağına sahip olan ve dışarıya bağımlı olan yerlere dışarıdan bir müdahale ile değerlendirilmeye alınmaktadır. Bu bir demiryolu olabilir, bir fabrikanın kurulması olabilir, ya da bir barajın yapılması. Burada o yerin dışarıya açıklı̆̆ının oranı da önemlidir. Genelde ulaşım biçimleri de bunda etkilidir. Ulaşım ne kadar açık ve kolaysa o yerin şehirle olan bağlantısı bütünleşmesi de o kadar kolay ve hızlıdır. Bölge olarak düşünüldügünde ekonomik yapı açısından homojen bölge, kutuplaşmış bölge, planlama amaçlı bölge olarak ayrıma gidildiğinde Ermenek'i görünüşte homojen bölge içine koyabiliriz. Ekonomik gelişme düzeyine göre ise gelişmiş, az gelişmiş, gelişme halindeki az gelişmiş bölge, potansiyel bakımdan az gelişmiş bölge olarak bir ayrım yapıldığında Ermenek'i az gelişmiş bölgeden gelişme halindeki az gelişmiş bölgeye doğru gittiğini nitelendirebiliriz. "Gelir seviyesi itibariyle ülke ortalamasının altında olmakla beraber gelişme hızı ülke ortalamasının üstünde olan bölgeler gelişme halinde az gelişmiş bölgeler olarak adlandırılmaktadır. Bölgedeki kaynakların yeterince değerlendirilememesinin yanı sıra, bölgeye özel veya kamu yatırımlarının çekilememesi, mevcut işgücü kaynaklarından faydalanılmaması sonucu bölge az gelişmişliğini sürdürmesine rağmen gelişmesini de sürdürmektedir" (Ildırar, 2004,s.12-13). Nitekim Ermenek 
önce kömür potansiyelini kullanmış sonra su potansiyelini kullanmış bir bölge olarak az gelişmişliğini sürdürmesine rağmen gelişmesini sürdüren, tamamen doğal kaynaklardan beslenen bir bölge niteliği taşımaktadır.

\section{Araştırmanın Yöntemi ve Örneklem}

Araştırmanın merkez alanı olarak, yapılan teorik çalışmanın örneğini ve uygulamasını oluşturan, Karaman'ın Ermenek ilçesidir. Baraj sularının altında kalan Çavuş köyü de yine bu mevkidedir. Araştırma, çalışmanın üç boyutunu yansıtacak şekilde Ermenek, Ermenek'in Çavuş köyü ve Konya olmak üzere üç farklı yerde yapılmıştır. Mülakat soruları tarafımızdan yüz yüze görüşme şeklinde gerçekleştirilmiştir. Bazı görüşmelere birden fazla kişi de katılmıştır. Çavuş köyünde ise odak grup şeklinde görüşmeler gerçekleşmiştir. Nitel görüşme yöntemi kullanılıp, mülakat sorularımız üç bölümden olmak üzere 24 sorudan oluşmaktadır.

Araştırmanın örneklemi, evreni temsil ettiği düşünülen çeşitli sosyokültürel özelliklere sahip Karaman'ın Ermenek ilçesindeki kişiler, barajın yapılması ile sular altında kalan Çavuş köyünün sakinleri ve Ermenekli olup Konya'da yaşayan ve bir dernek etrafında toplanan Ermeneklileri kapsamaktadır. Toplam 18 kişi ile görüşülmüsştür. Katılımcılar, barajla açıktan ilgisi olan, su altında toprağı kalan, mahkeme süreçlerini yaşayan, Devlet Su İşleri'nden beli bir meblağda para alan ve yakından bunlara tanık olanlardan seçilmiştir.

Mülakat yapılmadan önce alana gidilmiş gözlemler yapılmış, çeşitli kurumlardan veriler toplanmış, uzman niteliğinde sayılacak kişilerle ön görüşmeler gerçekleştirilmiş, yörenin köklü esnaflarıyla, mahkeme sürecinde dava alan avukatla, Esnaflar Odası ve ilçenin yerel haftalık yayın yapan gazete sahibi ile konuşulmuş, notlar tutulmuştur. Ermenek Belediyesi, Çavuş Köyü Muhtarı, İlçe Gıda, Tarım Ve Hayvancılık Müdürlüğü ile yapılan görüşmelerden istatistikî veriler sağlanmıştır. Konya'da ise "Konya-Ermenekliler Kültür, Sanat Ve Dayanışma Derneği"nin başkanı ile ön görüşmede bulunulmuş, Ermenek ile ilgili kaynaklar elde edilmiştir. Daha sonra asıl görüşmeler için yarı yapılandırılmış mülakat soruları oluşturulmuştur. 
Teorik kısımda ise önce Ermenek ile ilgili yazılı kaynaklar toplanmış, Mevlana Kalkınma Ajansının 2011 ilçe raporu ise ilçenin yakın tarihi açısından en detaylı hazırlanmış olan raporun bazı verilerine araştırmada yer verilmiştir. Yapılan mülakatlar ise toplumsal değişim ve dönüşüm çerçevesinde yorumlanmıştır. Alandan toplana veriler ve yorumlamalar sonucunda bulgular paylaşılmıştır.

\section{Köy, İlçe Ve Şehir Üçgeninde Sahadan Bulgular}

\section{Bölge Halkının Baraj Yapımına Bakışı}

Burada suyun metalaşması ayrıca işlenecek bir konudur fakat önce barajın getirdiklerine bakılacaktır. Şu anki barajın yeri tarım arazisiydi ve tarım yapılmaktaydı. Bütün tarlalar yapılan barajla su altında kalacağı tespit edildi. Ve bu tarlaların sahipleri olan ilçe halkına topraklarının değerleri hesaplandı ve halka paraları verilmeye başlandı. Pek çok kişinin elindeki toprak parçası yerini ellerinde belli miktarda parayla yer değiştirdi. Ve bu yer değiştirme ile halk elinde nakit para olmasıyla birlikte topraksız insanlara dönüştü. Tarlalarda suya verildi ve ilçe kır toplumu olma özelliğini kaybetti. Büyük oranda gıda ihtiyacını dışarıdan karşılamaya başladı. En önemli vasıf ise tarımsal ürünler olarak yetiştirilen tahıllardı. Çiftçilik azaldı, pazar açısından büyük bir değişiklik yaşandı. İlçenin ekonomisinde sermaye değişimleri yaşand. Makro anlamda ekonomik ve sosyal yapıda değişim yaşayan ilçe gündelik hayat anlamında da büyük değişimler ortaya çıktı. Yaşanılan mekân, tüketim alışkanlıkları ve yaşam tarzlarında olan değişimler ilk bakışta dikkat çeken durumlar oldu. İlçedeki ekonomik durumun değişmesi üretime de yansıdı. İlçe kendine yeterlilikten çıkıp dışarıya ve bir üst piyasaya bağlandı.

Mülakatlarda konuşmacıların, Ermenek barajına bakışlarında ilk vermiş oldukları cevap, Ermenek barajının büyük bir baraj olması yani büyük bir su kütlesinin yaratılmış olmasını yöreye farklı bir doğa manzarası getirmiş olduğuna dair olmuştur. Hepsinin diğer ikinci bir ortak görüşü ise verimli toprakların su altında kalmasına bağlı olarak barajın tahrip edici olduğudur. 
Su altında kalan yerlerin, Göksu nehrinin bulunduğu vadide yer alan verimli toprakların Ermenek' in tek tarım yeridir.Geçmişten bu yana kapalı bir yer olan Ermenek, Türkiye'de kendi kendine yetebilen kasabalardan biri olmuştur. Şimdi barajla birlikte yöre halkı bu yeterliliğin ortadan kalktığını söylemektedir. Fakat bunun göz göre göre kolayca olması, yapılan mülakatlarda görülmektedir. Baraj yapımına karşı çıkışlar çok az ve dağınık olmuş, örgütlü bir direniş olmamıştır.Enerji açısından ise Türkiye için faydalı Ermenek için kayıp olarak görülmektedir. Fakat Ermenek'te genel açıdan kayıpları olan bir yer olsa da baraj sonrası kendi içerisinde kazançlar elde edilmeye çalışılmakta olduğu görülmektedir. Örneğin balıkçılık yönünden umudu olanlarda olmuş, avcılık üzerine iki dükkân açılmıştır. Mülakat yaptığımız bu dükkân işletmecilerden biri de hem kayıp hem kazanç anlamında baraj hakkında görüşlerini belirterek bunu göstermiştir. Ona göre Ermenek barajı toprakların kaybolması gibi kayıplarının yanında kazanım olarak balıkçılığın öne çıkacağını söylemektedir. Bunun üzerine dükkân açtığını ve umduğundan da fazla satış yaptığını söylemektedir: "Ben barajdan bu kadar kazanacă̆ımı ummuyordum ama barajla birlikte çok olta sattım."

Tarımsal anlamda en keskin kaybı ise Çavuş köyü yaşamıştır. Bu köy tarımla geçinen kırsal yerleşim yeridir. Köylülerin arazilerinin dışındaki su altında kalan yerler, Ermenek merkezde yaşayanlar ve Konya'da oturanlarındır. Onlar için topraklarının su altında kalması Çavuş köyü kadar yıkıcı olmamıştır. Bu nedenle Ermenek barajı, zorunlu göç ettirilen Çavuş köylüsüne göre Ermenek halkından daha farklı şeyler ifade etmektedir. Yerinden yurdundan edilme psikolojisiyle yaşayan köylüler barajın mağdur tarafını temsil etmektedir. Çavuş köyü muhtarı şöyle anlatmakta:"Ermenek barajı bizi yerimizden yurdumuzdan etti. Köyümüz evlerimiz su altında kaldı. Çok sıkıntılar çektik. Kimisi parayı görünce hemen kabul etti kimileri de karşı çıkmıştı. Bize başka bir yer gösterdiler köy için. Fakat araziye ev yapmadılar. Su tutulduktan sonra ev yapmaya başladılar. O sıralarda biz Ermenek'e göçmek zorunda kaldık evlerimiz yapılıncaya kadar. O evleri de bize barajdan verilen parayla aldık tekrar. Devlet bize ne yer ne ev verdi yani sadece araziyi gösterdi o kadar. Herkes evi ve araziyi devletin bize bizzat tahsis ettiğini sanıyor. Oysa öyle değil. Bize bir dönüm müstakil ev ve bahçelik yer verdiler. Daha doğrusu sattılar. Bayındırlıktan 
kredi verdiler.Evi de kendimiz yaptırdık. Barajdan aldığımız maaşın üstüne bankalardan kredi çektik. Bize ne araziyi ne evi kendileri tahsis ettiler. Sadece araziyi gösterdiler. Fakat herkes devlet yaptırdı zannediyor. Ben şimdi bankaya 35 bin lira ödeyeceğim. Yaptırdığımız evlerde ipotekli. Ve 10 yıl boyunca da satma işlemi yapamıoruz." Bu mağduriyet her şeyden önce köyden ilçe merkeze göçe de sebep olmuştur. Dolayısıyla sadece şehre göç değil merkez ilçelere doğru bir hareketlilikte mevcuttur. Bu göçlerin pek çoğu da şehre göç etmeden önceki aşamadır.

Yine aktif olarak emek gücünde yer alan Çavuş köyünün kadınlarından biri de yaşadıklarını şöyle anlatmaktadır: “Üzüldük baraj yapılacă̆ını duyduğumuzda. Inanamadık. Ama ne yapıp ettiler bizi buralara koyuverdiler. Toprak yok, gelir yok. Önceden varımızı yoğumuzu kimse bilmezdi. Biz inanmadik suyun geleceğine. Kaymakam civar köylere dağılın dedi. Biz inat ettik dağılmadik. Bu evler vaktinde yapılmadı. Bizi oyaladılar. Son ana kadar bekledik bizi taşıyacakları yeri ama ne ev vardı ne arazi. Yaşlılar sıkıntıdan vefat etti. Akrabalarımız dağıldı. Nereye gideceğimizi bilemedik. Verilen sözler tutulmadı."

Köyün başka mağdur kadınlarından birisi de geçirdikleri süreci şöyle anlatmaktadır: "Eskiden köyümüzde sebze meyvemizin çoğunu satardık. İki tarafımızdan su akıyordu. İ̧me suyumuzda ücretsizdi. Benim en az 15 dönüm arazimiz vardl. Su tutulacak, can güvenliğiniz yok gidin dediler, elektriğimizi kestiler. Bütün köy 1 ay karanlıkta mum ışı̆̆ında oturdu. Söz verdikleri yeni gösterdikleri yerde ise ev yapmadılar. Bizde mecbur artık Ermenek'e kiraya gittik. Hayvanlarımızı ucuza sattık. Köydekilerin çoğu karamana Konya'ya göç etti. Ölümüzde dağıldı dirimizde. Mezarlarımızı taşıdılar. Burada şimdi küçük bahçemiz var ama su yok. Akarsuyumuz olsa yiyeceğimizi bari yaparız ama yok. Yapılan evlerde birbirine uzak. Kimsenin kimseden haberi yok. Komşumuz düşmüş ölmüş bir gün sonra gördük. Burada hayvan besleyecek yerimizde yok zaten ot yedirecek bağımız bahçemizde yok. Yaşlılarımız köylerinin yok olmasının üzüntüsü̈le vefat etti. Muhtarımız sıkıntıdan hastalandı vefat etti. Yaşlı bir komşumuz "beni köyüme gömün"diyerek öldü." Burada yerinden edilmenin psikolojisinin yoğun bir şekilde yaşandığı görülmektedir. Yaşadığı mekânın, toprağın yoksunluğunu çok güçlü hissedenlerin psikolojisi bu anlatılarda görülmektedir.

Toprakların değeri suyla ortaya çıkmakta iken Ermenek'te artık toprağın kalmaması suyun değerini insanlara göstermemektedir. Barajla birlikte suyun kısıtlandığını ama en çok suyu kullanan köyler açısından bu 
k1sıtlanmanın olduğu görülüyor. Ermenek halkı da suyun kendileri açısından değil köylüler açısından kısıtlanmış olduğunu söylemektedir. Nitekim Çavuş Köyü muhtarı: "Su halkındır devletin değil. Fakat şimdi suyumuzu bizden aldılar. Yeni taşındığımız yerde içme suyumuz bile yoktu, sondajla su çıkardılar" demektedir.

Ermenek dişında oturan Ermenek insanları ise dışarıdan Ermenek barajının her iki yönünüde görmekteler. Yani hem coğrafi açıdan oluşan değişim hem toprakların gidişi ve Ermenek'in en çok ihtiyacını karşılayan Çavuş köyünün su altında kalmasıyla oluşan durumu görmekteler. Fakat Ermenek ilçesindekiler mağduriyetin farkında değilken dışarıdaki Ermenek'liler bu mağduriyet hakkında hem daha çok bilgi sahibi hem de daha ilgililer.

Konya'da oturan Ermenekli emekli bankacı konuşmacımız ise şöyle anlatmaktadır: "Ermenek barajı Ermenek'in en verimli topraklarını alıp götürmüştür. Türkiye genelinde elektrik üretimi ile faydalı olması için yapılmıştır. Fakat Çavuş köyü açısından en kötüsü oldu. Artık oradan gelen sebzeler-meyveler yetiştirilemez oldu. Sebzecilik bitti, pazara artık dışarıdan geliyor, ancak istimlâk paralarından bir şey alındı onlarda bitiyor. Insanlar şehrin daha da yukarısına çıkmaya yaylacılık yapmaya, yayla evleri yapmaya başladı köylerde genç kalmadı. Araziler boş, eskilerde yapmaya yanaşmıyor. Gelir temin ediyor, "ben bir sene köyde kazandığımı şehirde bir ayda kazanırım" diyor.

Başka bir Konya'da oturan Ermenekliye göre ise görüşleri şöyle; " $E r$ menek barajının ÇED raporunu okudum. Enerjinin \%1'ini karşlayacak, enerji bakımından katkısı var. Bunun yanında ekili alanlar su altında kaldı. Raporun son cümlesi ise şu: Türkiye için kazanç Ermenek için kayıp." Buradan anlaş1l-yor ki bütün bunlara rağmen hala Ermenek barajının faydaları ve zararları üzerine somut bir şeyin olmadığı görüşü de yörede hâkimdir.

Suyun metalaşması ve baraj yapımları konusunda ironik bir şekilde "su boşuna mı akıyor" tartışmalarının karşılığında burada suyun kullanılmasa bile halkın yaşam hakkında nasıl bir yer ettiği görülmektedir. Mülakatlarda ve incelemelerde görülmektedir ki barajdan önce Göksu nehri kendi halinde akmasının yanı sıra Çavuş köyünün bu sudan faydalanmaktadır. Suyun belli bir alana kapatılması, erişim hakkının kısıtlanması, suyun hak mı ihtiyaç mı olduğu, suyun devletin mi halkın mı olduğu konusunda yöre halkının görüşleri suya olan bakış açısını farklı açlardan ortaya koymaktadır. 
Aynı şekilde Konya'da oturan dernek üyelerinden Ermenekli konuşmacımız köylülerin suya bakışıyla aynı beyanı vermiştir; "Önceden nehir köylüler tarafindan kullanılıyordu. Bütün sulamaları oradandı. Su Boşa aktı diyemeyiz. Sarıveliler ilçesine bağh Dumlugöze köyünden Evsin köyü hudutlarına kadar su kullanılıyordu. Barajla birlikte su kısıtlandı. Suyun değeri arttı. Fakat burada bir tezat oluşuyordu. Su artmasına rağmen kullanılamıyor. Bakanlığın, DSI'nin projesince yapılan şeyler. Halkın söz hakkı olmadı. Su öncelikle halkındır. Çünkü etrafinda yaşama hakkı çerçevesinde gerekir. Anayasal açıdan yaşama hakkı varsa o su onların hakkıdır." "Su halkındır" konusunda köylülerle Ermenek dışına göç etmiş insanlar hem fikirdir.

Ermenek'te ise "Suyun devlete mi halka mı ait" olduğu sorusunda ise cevaplar devlet tarafına çıkmaktadır. Barajdan önce "su halkındır" diyenler barajla birlikte "su halkındır yani bizimdir" görüşünü sürdürmemiştir. Hangi açıdan düşünülürse düşünülsün sonunda "su devletindir" düşüncesi ortaya çıkmaktadır. Örneğin Ermenek içinde yaşayan söz sahibi inşaat sektörünün mimarına göre bu konuda ise kesin şekilde devletçi görüşündedir:"Baraj suyun değerini artırdı. Su bir hak değil ihtiyaçtır. Halkın değil devletindir. Halk serbestçe kullanamaz. Baraj yapılan yerlere de enerji kullanmada ayrıcalık tanınamaz çünkü sinırı nerede keseceksiniz?"

Suyun bir ihtiyaç mı hak mı olduğu konusunda ise hepsi ihtiyaç olarak görmekle beraber çoğu da aynı zamanda hem ihtiyaç hem hak olarak görmektedir. Örneğin; Ermenek esnaf odası başkanı şöyle demektedir: “ Baraj suya erişim hakkımı kısıtlamadl, fakat kullanmak istesem erişme hakkım yok, suların değerini de artırdı. Su önce ihtiyaçtır. Ama suyun yanında olsaydım yani tarlam bağım bahçem olsaydı suyu hak olarak görürdüm. Çünkü su orada yaşayan insanlarındı ve bir bakıma bizimdi." Buradan şöyle bir sonuç çıkmaktadır: Ermenek içinde yaşayan ile Çavuş köyünde ve Ermenek dışında yaşayan insanlar arasında suyun kime ait olduğu noktasında ayrılmaktadır.

Barajın yaratmış olduğu toprak kaybına rağmen baraja karşı çıkışların olup olmadığı konusunda ise değişik fikirler görülmektedir. Yapılan mülakatlarda örgütlü bir karşı çıkış olup olmadığı olduysa ya da olmadıysa neden ve şimdi fikirlerinde ne değişiklik olduğu konusunda ise farklı fikirler görülmektedir.

Ermenek İlçesi, baraj yapımıyla ilgili olarak 1960 yıllarından beri incelenmekte olup, çeşitli ölçümler yapılmaktadır. Ermenek halkı da bunu bil- 
mektedir. O günden bu yana karşı çıkma adına ses çıkmamıştır. İnşaat yapımı başladığında da Ermenek halkı direniş göstermemiştir. Hatta Ermenek halkı barajı çare olarak görmüş, ilçeye faydalı olacağını düşünmüştür. Örneğin bu konuda barajda beş yıl çalışan şöyle düşünmektedir: "Ermenekte yapılan baraja karşı çıkmadık. Ermenek'te çok işsiz olduğu için, kömür ocağında çalışmakta zor olduğu için, Ermenek barajı iş kapısı olarak görüldü. Ermenek'te pek çok genç maaşı önemli değil yeter ki çalışalım diyorlardl."Kendisinin de belirttiği gibi Ermenek barajında Ermenek insanları gençleri bir müddet çalışma imkânı buldu. Kömür ocağına göre iyi bir alternatifti.Baraj yapımıyla birlikte köylerinin su altında kalacağını öğrenen Çavuş köyü ise önce inanamamış, kabullenememiş taşınma konusunu ciddiye almamıştır. Kendilerine tam olarak tarih de verilmemiş ne olacağını köy halkı kestirememiştir. Kendilerine başka köylere dağılması konusunda fikir verilmiş köylü kabul etmemiştir. Yine köy muhtarı şunları söylemektedir: “Baraja karşı çıkmıştım ama bizi dinleyen olmadı zaten. Hatta ben barajda çalışmak zorunda kaldım. 4,5 yıl. Tarım işimizi kaybetmiştik. 600 küsür maaş alıyordum. Başımızdaki muhasebeci Türk idi. Yabancı şirket kadar maaş alamadım."Baraj yapımına karşı Ermenek halkı karşı çıkmadığı mülakatlarda ve diğer gözlemlerde de görülmektedir. Hala da bu değişmemiştir. Çavuş köyü ve Ermenek dişındakiler ise hala karşı duruşlarını değiştirmemiş, yapılmaması düşüncesiyle geriye dönük düşüncelerini sürdürmektedir.

\section{Barajla Piyasaya Giren Para ve Toplumsal Mobilite}

Barajın sağlamış olduğu istimlâk gelirleri ise Ermenek'in hayat seviyesinde değişiklik yapmış, bununla beraber bunu başka değişiklikler takip etmiştir. Genel olarak mülakatlarda da yaşanan bu değişikliğin hayat seviyesinde nasıl bir yükselme gösterdiğini ortaya koymaktadır. Şu kesin olarak görülmektedir ki, Ermenek barajı toprak sahiplerine büyük bir ekonomik hareketlilik getirmiştir. Su altında kalacak toprakların sahipleri belirlenmiş, toprak analiz edilmiş, üstündeki ağaç vb. bitkiler cinsine, yaşına göre incelenmiş fiyat biçilmiştir. DSİ toprak sahiplerine belirledikleri fiyatı sunmuş, tapularını da istemiştir.

Küçükten büyüğe kadar hemen herkesin toprak sahipliği vardır. Raporlara göre de 2820 kişi kamulaştırma bedeli almıştır. Ermenek içinde kalan miktar ise sosyo-ekonomik değişimi başlatmıştır. Mülkiyet olarak 
öncelikle insanlar gayrimenkul almışlardır. Ev en başta yatırım yapılan mülkiyet olmuştur. Bu da apartmanlaşmayı hızlandırmıştır. Eski dam evi olanlar apartman dairelerde yaşamaya başlamışlardır. Eski bahçeli evdeki uğraşlar, kısmen de olsa kendi ürettiklerinin yerini hazır tüketim almıştır. Bu da insanları marketlere yönlendirmektedir. Her istediğini istediği zaman toplu alabildiği marketlerden eski ihtiyaçlarını karşılamaktadır. İkinci mülkiyet olarak taşıt alımı fazla olmuştur. Bunun dışında herhangi farklı bir yatırım türü olmamıştır. Parayı harcama noktasında herkes aynı tutumu göstermiş, aynı şeyleri yapmıştır. Dernek başkanı bu noktada gözlemlerini şöyle anlatır: "Ermenek şimdiye kadar bu kadar büyük para almamıştı. Ama aldı̆̆ı parayı değerlendiremedi. Ev aldı, araba aldı. Ehliyeti olmayan bile araba aldı. Başkaları aldı biz de alalım diyerek. Yani parayı ne yapacakların bilemediklerinden herkes birbirine baktı öyle parayı harcadı. Bu nedenle de yatırım yapılamadı. Paranın da devamlı bir getirisi olacak dönüşüm olmadı."

Hayat seviyesinin yükselmesine yardımcı olarak ikinci basamak barajla birlikte bir süreliğine iş sahasının oluşmasıdır. Özellikle gençler için iş kapısı olmuştur. Özellikle yabancı şirket bu anlamda büyük katkı sağladığı görülmektedir. Barajda ofis elemanı olarak çalışan konuşmacımıza göre ise barajda çalışanları ve şirketler hakkında şöyle demektedir: “Ben ofis elemanı olarak 5 yıl Pöyry şirketinde çalıştım. Yabancı şirket bayramlarda mesela 30 ağustosta tatil verirdi bize ama Türk şirket vermezdi. Bizim haftalik tatilimiz cumartesi öğlen başlar pazartesiye kadar ama Türk şirket 15 güne bir tatil yapardı. Biz günde 8 saat alışırken Türk şirketi 12 saat ve daha fazla çalışyordu. Barınma yeme içme yabancı şirkette daha iyi idi. Yabancı şirkette bir vasıfsız işçi 2000-3000 arası maaş alırken Türk şirketi 800 ve yukarısını alıyordu. Bazı mühendisler Ermenek'ten ev tutuyordu. Ve bunların çoğu yabancı idi. Örneğin Türkiye'de baraj gövdesi patlatmasını bilen çok az olduğu için dışarıdan gövde patlatma için mühendisini getiriyorduk. DSİ kiralıyordu."

Başka bir açıdan yine Ermenek içinde oturan mimar konuşmacımız ise şöyle anlatmaktadır: "Tabi, hayat seviyesinde belli bir yükseliş oldu. Bir girdi sağladı. Yaşam tarzlarım değiştirdi. Bu bir örnek oluşturdu. Baraj dışındaki insanlarm birikimlerini de etkiledi. Onlarında alım satma işleri gerçekleşti."

Ermenek barajı ile başlayan baraj istimlakları ilçede diğer kamulaştırmaları getirmiştir. En son çevre yolu projesi başlatılmıştır. Amaç ilçenin zaten dar ve dik yollarını rahatlatmak ve kömür taşıyan büyük taşıtlarının 
çarşının dışından geçmesini sağlamaktır. Projeye göre ise yol yöre halkının bağlarından geçecektir. Buna göre kimlerin bağından geçecekse belirlenmiş, çağrılmış, fiyat belirlenmiştir. Çoğunluk kabul etmiş imzaları atmışlardır. Bu bağların içinde çeşitli ağaçlar olmak üzere bitki çeşitliliğini barındırmaktadır. Fakat toprak eskisi gibi işlenmemekte olup boştur. Devlet bu projede bağ sahiplerine yine yüksek fiyat vermiş bu nedenle itiraz eden olmamıştır. Yine bu istimlâk fiyatları Ermenek için gelir olmuştur.

\section{İstimlâk Paraları Ve Yaşanan Hukuki Ve Toplumsal Sorunlar}

Yapılan kamulaştırma bedelleri ile yoğun mahkemeler yaşanmış, mağduriyetler söz konusu olmuş bunun ise giderilip giderilmediği bölgede çeşitli tartışmaların ortaya çıkmasına yol açmıştır.

Baraj altında toprağı kalanlardan konuşmacılarımızdan biri şöyle anlatmaktadır: "Başlangıçta DSİ düşük fiyat verdi. Yapılan itirazlarla ilk etapta yükseldi. Ama üçüncü, dördüncü etapta DSİ kamulaştırma politikasını değiştirmedi. Tam tersi daha da aşağı çekti. Mahkemeler daha da arttı. Mahkemelerde de fiyatlar $3-4$ kat arttı ama hala DSİ geri adım atmadı. $\mathrm{M}^{2}$ ye 2,5-3 liradan belirlendi, davalarla 7-7,5 liraya çıtı. Ardından 1,5-1,9'a düşürdüler. Yapılan itirazlara da devlet, insanlara mahkemeleri gösterdi, kazanırsanız verelim düşüncesiyle. Çoğu da kazandı. Ama bu arada en çok avukatlar kazandı.

Yine yörenin köklü esnaflarından bir konuşmacımız ise mahkeme sürecini şöyle anlatmaktadır: “DSİ bizi mahkemeye verdi. Birinci etapta parayı alınca tapularımızı verdik, 2. Etapta ise değeri düşük verdiler bizde tapumuzu vermedik. Bu şekilde mahkemelik olduk. Önce 60 bin almıştık, mahkeme 1 sene sürdü, avukat tuttuk, 33 bin lira daha aldık.\% 10 nu da avukata verildi."

Konuşmacılardan biri ise yaşadıkları mahkeme sürecini şöyle anlatmaktadır: "Bizim mahkeme sebebiz şuydu: bize 2 dönüm parası kestiler önce 1 dönümünkini verdiler. 2. Dönümümde mahkemelik olduk. Aslında devlet kendi kendini mahkemeye verdi. Biz vermedik. 2. Dönümün parasını alıncaya kadar mahkemeyle uğraştık. Bununda aslında oyalama olduğunu anladık. Devlet bütün olarak veremedi parayı. Parça parça verebildi." 
Yine esnaf konuşmacılarımızdan biri şöyle anlatmaktadır: "Kamulaştırma nedeni ile yoğun mahkemeler yaşandı. Nedeni ise; vatandaşın kamulaştırmadan düşük aldığını, devletinde yüksek verdiğini düşünmesi anlaşmazlıklara yol açtı. Arazilerin değeri verilirken belli şeylere göre belirlendi. Toprağı ayrı, toprağın üzerinde yetişen ağaçlara ve o ağaçların cinsine, yaşına bakılıp, ayrı ayrı değeri ölçüldü. Üzüm, ceviz ve kiraz en çok değer edenlerdi. Su basmayan kıraç kısımlara daha az verildi. Bu mahkemelerle avukatlara büyük bir rant çıktı. \% 15-20 ile çalıştılar. On binlik araziye 20 binle kazanırız ama 10bini bölüşürüz vaadiyle anlaştılar. Bu davalarda kazananlar daha fazla. Sonuçta vatandaş yinede güzel para ald1."

Sonuç olarak devletin büyük oranda, istimlâk bedeli olarak yüksek meblağlar ödediği görülmektedir. Her ne kadar yoğun mahkemeler olmuşsa da sonunda devlette eski hesaplara dönerek tekrar hesaplamış ve vatandaşa geri ödemeler yapmıştır.

Mahkemeler dışında yaşanan en büyük sorunlardan biri de Çavuş Köyünün iskân problemi olmuştur. Köyün nereye, ne zaman, nasıl taşınacağ1 önceden belirlenememiş, köylüde gitmek gibi bir şeyi kabul etmek istememiştir. Onları tatmin edecek, eski hayatlarını aynen devam ettirebilecek bir yer belirlenmemiştir. Barajın bitip, su tutmasına yakın zamanlarda köylüyü alelacele bir yere taşımak gibi bir duruma düşmüşlerdir. Bu konuda pek çok haber yapılmış olmasına rağmen de DSİ kendini savunmuş, geri adım atma ya da köylüyü tatmin edecek bir yer bulma girişimine çaba göstermemiştir. Yerel ve ulusal pek çok gazetede bununla ilgili haberler çıkmıştır. Örneğin; hürriyet gazetesinde "su altında kalacak köylerini terk etmiyorlar" başlı̆̆ıyla yapılan haberde bunca şeye rağmen sonunda taşınmayı kabul eden köylü en azından taşınma için verilen 30-40 günün uzatılmasını istemektedir. Gazeteye konuşan köylülerden biri "köyün taşınacağı alanda parsel düzenleme çalışmaları ise bize bu haberin gelmesiyle başladı. Yeni yerleşim yeri alelacele kepçeyle düzeltildi, parseller belirtildi. DSİ yetkilileri, 'buralara evlerinizi yapın ve 3 Nisana kadar taşının' dediklerini söylemektedir" (Hürriyet Gazetesi, 2009).

Diğer bir gazete ise "gazete ilanı ile davalı arıyorlar" başlığı ile yaptığ haberde, Karaman'ın Ermenek ilçesinde açılan bir kamulaştırma davasının sonuçlanabilmesi için davalı konumdaki 168 kişi ve varislere ulaşabilmek amaciyla Ermenek Asliye Hukuk Mahkemesi'nce ulusal gazeteye 2.5 
sayfa ilan verdi" (Sabah Gazetesi, 2009). Gazete ilanlarıla davalı arayan DSİ bir an önce vatandaşa açtıkları davaları sonuçlandırmak istemektedir. Haberin devamında ise Çavuş Köyünün muhtarının verdiği bilgi yer almaktadır: "'Ermenek'in sebze ve meyve ihtiyacı tamamen Çavuş köyünden karşılanırdı. Köylümüz çiftçilikten başka bir iş bilmez. 2005 yılında kamulaştırma çalışmaları başladığında bize çok komik paralar teklif ettiler. DSİ'nin bize teklif ettiği paraları bizler 2-3 senede o topraklardan kazaniyorduk. Biz itiraz ettik mahkemeye verdik. DSİ de bizleri mahkemeye verdi. Bu dava sürüp geliyor. Bizler avukat tuttuk. Avukat davamızı takip ediyor. Bize önceden de tebligatlar yapıldı. Gerekli itirazlarımızı yaptık. Şimdi araziler su altında. Birçok kişi başka şehirlere göç etmek zorunda kaldı. Zaten ilçede aynı şartları taşıyan toprakları para ile bulup satın almak da mümkün değil" (Sabah Gazetesi, 2009). Bunun yanında pek çok yerel gazetede de haberleri yapılmış, sosyal medyada pek çok kaynak tarafından işlenmiştir.

\section{Kalkınma Politikasına Siyasal Bakışlar}

Yapılan mülakatlarda kişilerin toplumsal, siyasal, kültürel katılımlarının olup olmadığı konusunda ise farklı cevaplar söz konusu olmuştur. Bu başka bir araştırmanın konusu ama Ermenek'te siyasal katılımın yüksek olduğu ortaya çıkmaktadır. Mülakatımızda da Ermenek'in kanaat önderleriyle görüşüldügü için de siyasal katılımın yüksek olduğu ortaya çımıştır. AKP, MHP ve CHP olmak üzere üç partinin ağırlığının fazla olduğu görülmekte, esnaf ve sanatkârlar odası, avcılık, atıcılık, sulama kooperatifi, mimarlar odası gibi birliklerde üyelikler bulunmakta, Konya'dakilerin ise Ermenek Kültür Sanat ve Sosyal Dayanışma Vakfına (KONER) üyelikleri bulunmaktadır. Özellikle Konya'da dernek etrafında toplananlar aktif şekilde hemşehriliğin güçlü olduğunu göstermektedirler. Baraj konusunda tarihi Alaköprü'nün kurtarılması için de Kültür Bakanlığına bazı başvurularda bulunma girişimlerini göstermişlerdir. Sadece Konya değil Ankara, İstanbul, İzmir, Antalya gibi şehirlerde de dernekleri bulunmakta ve bütün Ermenek'liler buralarda birleşmektedir. Sadece siyasal katılım değil okuma oranının yüksek olmasına bağlı olarak başka alanlarda da girişimciliğin ve dayanışmanın yüksek olduğu görülmektedir. 
Siyasal katılımın yüksek olması, devletin üst kademelerinde yöre insanından siyasetçi ve bürokratlarında bulunması, bu yere yapılan baraj konusunda nasıl bir tavır sergilediği merak edilen bir bağlantı olmaktadır. Yapılan mülakatlar ise bu konuda tam bir tavrın söz konusu olmadığını göstermektedir. Fakat kamuoyu bu barajın yapılması konusunda kendilerine başvurulmasını önemsediğini görüyoruz.İlçe halkı, siyasilerin tutumları konusunda pasiflik gösterdiklerini, baraj konusunda ise halkın görüşlerinin alınmadığı görülmektedir. Fakat ilçe halkı barajın yapılmasını çok önceden beri beklemektedir. Fazla iş sahasının olmadığ 1 ilçede baraj bir iş sahası olarak görülmektedir.

Bu konuda bölge halkından görüş verenlerden biri şöyle demektedir: “ Koalisyon zamanında bu barajın temeli atılmıştı. Ondan öncesinde uzun yıllar ölçümler yapılıyordu. Siyasilerin karşı olma gibi bir tutumları olmadı. Ama bölge halkı bilgilendirilebilirdi. Ayrıca enerji nakil hatları kendi istimlakları olan yerlerden geçirilmedi, insanların bağlarından düzensizce geçirildi. Ve bu bağlar talan oldu." Başka bir konuşmacımıza göre ise baraj konusunda siyasilerin ve halkın tutumunu karşılaştırdığında şunları söylemektedir; "siyasilerden daha çok halkın isteğinin çok olduğuna dair dikkat çekici bir tutum olurken, siyasilerin ise kesin, net bir tutumları olmamıştır. Baraj yapılmasaydı zaten insanlar üzülecekti. Benim dükkânıma (eczane) sık sık gelip soruyorlardı ne zaman yaptlacak bu baraj diye. Millet bir an önce para almak istedi."

Genel olarak halk baraj yapılmasını isterken siyasilerin ve uzmanların baraj konusunda olumlu-olumsuz gelişecek durumlar hakkında herhangi bir bildirileri olmadığı için pek çok kişi barajın olumsuzluklarının bilincinde olmadığı için barajın yapılmasını istemiş olduğu görülmektedir. Diğer yandan mağdur olan Çavuş köyüne siyasilerin önlemleri, destekleri olmamış, devlete ve siyasete olan güvenlerinde azalma olmuştur.

\section{Toprak, Şehirleşme ve Göç}

Barajla birlikte ilçede toprak dengesi değişmiş, toprak alım-satımları, fiyatları, yetiştirilen ürünlerdeki çeşitlilik, hala toprağı olanların baraj sonrası fiyat konusundaki piyasadaki tutumları ve toprakla olan ilişkisi ilçenin ekonomisi ve tarımına ne şekilde yansıdığı mülakatlarda görülmektedir. 
Ermenek ilçesindeki insanlar küçüklü büyüklü toprak sahibi insanlardır. Bir kısmı tarlasına, bağına, bahçesine kendi bakmakta, bir kısmı ortağa vermekte, bir kısmı da ilgilenmemektedir. Eskiden ortakçılık daha yaygınken şu an toprak sahibi hiçbir şey istememekteyken, "yeter ki ağaçlar kurumasın, içine istediğini ek, toprağı her açıdan kullan" deseler de çok azdır. İnsanlar artık toprakla uğraşmamakta dolayısıyla ortakçılık yapan kimsede kalmamıştır. Ortakçılığı daha çok şehirlere göç etmiş, toprağını satmamış kişiler aramaktadır. Onun dışında da istediği fiyata satamadığı için kamulaştırmaları, örneğin, bir yol geçmesini beklemektedir.Toprak fiyatları ise bulunduğu yere göre değişmektedir. Fakat baraj yapıldıktan sonra bu değişim daha da artmıştır. Baraj manzaralı yerlerin, baraja yakın yerlerin fiyatları en yüksek fiyatlı yerler olarak geçmektedir. Baraj manzaralı yer alıp içine ev yaptırıp, bahçecilik yapanlar artmıştır. Eski bağcılık yerini daha modern şekilde yeniden bağcılık, bahçecilik almıştır. Topraktan kopamama hala mevcuttur. Örneğin hala toprakla uğraşan konuşmacılardan biri;" toprak hayattır, her şeydir. Hala toprağımızla uğraşıyoruz, tohumlarımı eskilerin tohumları. Her yıl ektiğimizden tohum saklıyoruz, yerel, buraya özgü tohumlarımızı ekip dikiyoruz, gübre ve zirai ilaçlarda kullanmıyorum. Geleneksel işler, aynen devam ettiriyorum" demektedir.

Fakat diğer yandan esnaf odası başkanı: "Insanlar yaylalardan yer aldl, zeytine ağırlık verildi. Su altında kalan Çavuş köyü pazara en çok sebze meyve getiren köydü. Ürünleri daha kaliteli idi. Daha çabuk oluyor, pazara erkenden bazı ürünler geliyordu. Şimdi başka köylerden geliyor ama Çavuş köyü kadar iyi değil. Eski pazarımızdaki ürünlerin kalitesini arıyoruz" demektedir.

Toprak konusunda en duyarlı insanlar ise Çavuş köyüdür. Köylünün bütün hayatı toprağa bağlı olduğu için daha hassastırlar. Bir anda bütün topraklarını kaybedince büyük bir yoksunluk yaşamışlardır. Köyün kadınlarından biri;33 dönüm arazimiz vardı, sene de üç çeşit sebze kaldırırdık. Pazarda satardık, zor zoruna bağ kur yaptırabildik. Gelirimiz tarımdı her şeyi yapardık. Şimdi taşın içindeyiz. Küçük bahçelerimiz var ama hortumla sulama olmuyor. Bizi taşıdıklar bu yer taşlı bir yer. Tarım yapılamaz. Marketten almak zorumuza gidiyor şimdi. Hayatımız boş geçiyor. Bizim için toprak altındı. Bir avuç toprak her şeydir. "zaman gelecek bir poşet toprak altın kesecek" demektedir. Bu beyan kırsal insan tipolojisini çizmektedir. Yani "toprağın bireysel tahsisi sayesinde yalnızca kollarının gücüne sahip olabilen insanlar var 
olabiliyor. Bir insanı boşluğa koyduğunuzda, onun havasını soymuş olursunuz. Toprağı ondan aldığınızda da aynı şeyi yapmış olursunuz. Çünkü böylece o kişiyi zenginlikten yoksun bir mekâna koymuş ve böylece onu sizin arzularınıza boyun eğmek dışında her türlü yaşama yolundan mahrum birakmış oluyorsunuz" ( Foster, 2001, s.231).

Yine Çavuş köyü muhtarı "Göksu nehrinin yanında sahil köyüydük. Bütün sulamalarımızı bu nehirden yapıyorduk. Toprak bizim için rızıktı. Ayrıca sadece bizim köyümüz değil yaklaşık 10 köy barajdan etkilendi. Onlarında tarımları da kısmen olsa bitti" demektedir.

Ermenek esnaflarından konuşmacılarımızdan birine göre ise ilçenin tarım yönünden kısıtlı olduğuna dair yorum yapmıştır. Kendi tarım uğraşlarını şöyle anlatıyor: "Şimdi elimizde 4 dönüm üzüm bă̆ımız var fakat barajla birlikte iklimin nemli olmasıyla mantar hastalı̆̆ı çoğaldı. Artık üzümlerimiz de eskisi gibi değil. Fazla artış olmadı. Kimse ekip kaldırmıyor". Burada ekolojik bir dengenin de bozulduğuna, bazı ürünlerin eskisi gibi olmadığına konuşmacı dikkat çekmektedir. Nitekim Doğa Derneğinin yaptığı araştırma da bu bağlamda çarpıcıdır. "Araştırmalarına göre barajla birlikte 6500 hektar toprağın su altında kalmasıyla dünyada sadece burada yaşayan VerbascumLeuconeurum isimli bitki türü yok olacak, barajla birlikte Ermenek bölgesinde yaşayan 123 bitki ve hayvan türü daha nesli tükenme tehlikesi ile karşılaşacaktır"(Doğa Derneği, 2012)

İstimlaklar yapılırken bu esnada devletle olan çeşitli sorunlar oluşmuştur. Bu da insanları toprak için bir mücadeleyi sokmuştur. Fakat bu süreçlerin ağır ve zorlu geçmesi nedeniyle peşini bırakmak zorunda kalmaktadırlar. Konya' da ki Ermenek'li bir konuşmacımıza göre;"Ermenek'in Görmeli köyünde bir tarlamız vardı fakat devlet, etrafı ormanla çevrili diye elimizden aldı. Oysa yol geçiyordu yanından. Mahkemeye başvurduk mahkeme bize verdi tarlayı tapumuzda vardı fakat Yargıtay kararı bozdu ve tekrar aldılar. Bir daha da uğraşmadık. 12 dönüm tarlamız var. Ortağa verdik, ek kaldır hepsi senin olsun dedik, onlarda nohut, buğday ekip kaldırıyorlar. 4 dönümde bağımız var, orası da ortakta yarısına ekiyor yarısında da hayvancllık yapıyor. Ürünleri satmıyor ara yerde belki bazen eşe dosta veriyordur o kadar. Ürün çeşitliliğinde de bir şey yok."

Mimar konuşmacımız da barajdan sonra bahçe almış, toprakla uğraşmaya başlamıştır. Fakat bahçesinde çalıştıracak, bahçecilik yapacak birile- 
rini bulamadığını söylemektedir. "Toprağa bağımlılık azaldı. Tarımla uğraşanların sayısı azaldı. Yapanların çoğu da hobi olarak yapıyorlar. Kalanlarda yol geçsin diye bekliyorlar. Ben bahçem için bakacak aile ya da eleman arryorum, içindeki evi veriyorum kalması için altına araba veriyorum ama kimse bakmıyor. Ancak doğudaki Kürt olursa toprağı işler, bakar. Inşaat işlerimizde de zaten hep dişarıdan işçi getirtiyoruz yıllardır. Kamulaştırma burası için bir piyango oldu. Bu kadar para alınacağı da tahmin edilmiyordu."

İktisadi değişimin yansımalarından biri de açllan yeni marketler olmuş, yörenin yerli küçük esnafının durumu ise bu noktada merak edilmektedir. Ermenek ilçesinde son beş yıl içerisinde açılan marketler esnafı rahatsız etmiştir. Halk marketlere yönelmeye başlamış, bakkallardan alışveriş yapan azalmıştır. Fakat Ermenek ilçesi yıllardır mümkün olduğunca şehirlere gittiğinde alışverişini yapmaktadır. Sağlık için Karaman, Konya'ya giden halk pek çok alışverişini de oralardan yapıp gelmektedir. Onun dışında sık gitmeyenler Ermenek'ten yine yapmaktadır. Konuşmacılardan biri bu konuda şunları anlattı:"Marketler olmayınca bize esnaf her şeyi pahalıya satıyordu. Pazar mafyalaşmış, dışarıdan gelenlere yer vermiyorlar, dolayısıyla ürün fazla olmayınca pahalı almak zorunda kalıyoruz. Eskiden (şimdi su altında kalan) köylü varken biraz daha ucuza alıyorduk ama o köylerde artık olmayınca pahalılık arttı." Yani eskiden tarım yapılan köyler pazara geldiğinde ürünlerde ve fiyatlarda da çeşitlilik vardı. Dolayısıyla halk her fiyattan ürün bulabiliyordu ve alıyordu. Şimdi bu ürün azalması fiyatları da yükseltti dolayısıyla halkı ucuz, toptan kampanyalar yapan marketlere yöneltti.

Barajla birlikte yörede balıkçılık ve su sporları gibi turizm imkânı sağlayacak piyasanın yaratılmasına çalışılmaktadır. Yörenin turizmi konusu çok konuşulmasına rağmen balıkçılık henüz yeni yeni küçük çapta yapılmaya başlanmıştır. Su sporları kulübü kurulmuşsa da daha sonra durmuştur. Halk bu konuda belediyeye görev düştüğünü, tanıtımların yapılması gerektiğini söylemektedir. Konya'da dernek başkanı şunları söylemektedir: "Barajın turistik açıdan kazandırılması için görsel manzara ve çevresinin iyi değerlendirilmesi gerekir. Tarih ve turizm yönünden gündeme gelip tanıtılması gerekir. Ermenek iki defa tarih başkenti olmuş bir yer. Türkiye de Türk dokusu bozulmamış iki yerden biri Bursa-Yenişehir diğeri karaman Ermenek ilçesidir. Bunu tarihçi İlber Ortaylı'da söylemiştir. Ermenek, dayanışması yüksek 
bir ilçe. Çünkü eskiden beri biz kendi kendimize dayanarak yettik. Dışarıdan hiçbir şey gelmiyordu bize. Her şeyimizi kendimiz yapıyorduk. Bu nedenle hala bu dayanışma başka şehirlere göç edenler arasında da sürüyor. Doğasıda sert olduğu için insanına tesir etmiş, bu nedenle hem doğa açısından hem sosyal açıdan pek çok zorluğa dayanabilir. Sonuç olarak burada turizm gibi bir imkânın çıkması devlet destekli yerel yönetimlerin becerisine bağll."

Bölge halkından 2820 kişi kamulaştırma bedeli almış ve ilçeye ilk defa bu kadar büyük bir istimlak bedel girişi olmuştur. Yapılan mülakatlarda bütün kişiler Ermenek'in daha önce böyle büyük para ile karşılaşmadığını söylemektedir. İlçe halkında gözle görülen ilk değişiklik ise genelde daire ve araba alması olmuştur. Ermenek esnaflarından konuşmacılarımıza göre: "Insanlar ilk önce ev, araba aldılar. Cenne köyü tamamen şehre (Konya'ya) göç"müştür. Bazı köylerde zorunlu göçe tabi tutulmuş gibi gözükmüyor ama barajla birlikte dolaylı yoldan göçmek zorunda kalmış ya da göçme kararı vermelerinde etkili olduğu görülmektedir.

Bununla birlikte Ermenek'in sanayi, hizmet sektörlerinde bir gelişme olacağ1 düşünülse de konuşmacılar bunun çok zor olacağını tahmin etmekteler. Eski yıllarda Ermenek'te zanaatçılık yaygınken işsizlik gibi bir sorun yoktur. Fakat zanaatçllk bitince makineleşmeyle işsizlik sorunu çıkmıştır. Bölgenin tarihsel olarak göç veren bir yer olması nedeniyle kalkınmanın burada öncelikli düşünülmesi bu nüfusu yerinde tutabilmek ve kamulaştırma bedelleriyle halkın gitmesini önlemekti.fakat bu bölgede kalkınma böyle bir işlevi tam anlamıyla görememiştir. Konuşmacılarımızin beyanlarından biri bunu göstermektedir: "Barajdan verilen paraların Ermenek'te ancak \%30 -35 'i kalmıştır. Zaten büyük arazi sahiplerinin çoğu dışardaydr. Bu insanlarda zaten Ermenek'in köklü, zengin aileleri idi. Bunlar dışarıya göçtüler ve Ermenek'e yatırım yapmadılar. Buradaki insanlarda aldıkları para ile de ilk olarak genelde ev, araba aldılar."Ermenek ilçesinde ulaşım sorunu sosyo-ekonomik pek çok yatırımı engellemektedir. Dışarıdan hammadde getirmenin maliyeti yüksek olduğu için fabrika ve benzeri işletmeler açılamamaktadır. İlçe halkı bu nedenle de yıllardır dışarıya eğitim nedeni ile göç vermektedir. İş sahası olmaması sebebiyle okuma tek çare olarak görülmektedir.

Konuşmacılarımızdan esnaf odası başkanı ise, Ermenek'tekiler şehirlere köydekiler Ermenek'e göçmesinin ve bu yer değiştirmenin sonunda yabancılaşmanın nasıl oluştuğunu vurguluyor.“Köylerden çok fazla göç var. 
Şehirden tekrar dönen ise \% 1-2'dir anca. Köyden gelenler yabancı olarak görülüyor. Şimdi Ermenek içindeki insanla köydeki insan aynı apartmanda buluştu. Ama yabancı olarak gördükleri için iletişim yok."

Diğer yandan barajın getirdiği ekonomik gelir köy, ilçe ve şehir üçgeninde bir yer değişimi yapmıştır. Ermenek ilçesindekiler şehirlere göç ederken köylerde Ermenek ilçesine ve az da olsa şehre göç etmiştir. Bu nedenle ilçede nüfusun bu değişimi eski sosyal, ekonomi ilişkilerini de değiştirmiş, yeni ilişkiler başlatmıştır. Ermenek halkı tarafından yabancı vurgusu yapılmaya başlanmış, eski ilişkilerin kalmadığı görülmüştür. Ermenek kasabasının köye bakışı burada merkezin çevreye olan bakışına benzer. "Anadolu şehirleri ve kasabaları kıyıda olmaktan köyler vasıtasıyla kurtulurlar. Köy varlığıyla, taşralıya şehirli olduğunu hatırlatır, kasabalı kendini köylü karşısında daha modern ve medeni bir kimlik ve mekân içinde algılar. Denge köylünün kendine en yakın kasaba ve taşra şehrine değil de merkeze yani büyükşehre göçmesiyle bozulur. Dünün köylüsü şimdi kendisini taşralı karşısında daha "kentli ve daha merkez" olarak görmektedir"(Barbarasoğlu, 2011, s.247-48). Ermenek kasabasında da böyle bir denge bozuluşu yaşanmıştır.

Konuşmacılarımızdan bir tanesi ise şöyle anlatmaktadır: "Devlet yatırım yaparsa nüfus belki durabilir. Fakat buraya yapılan okullar, otel hep bu bölgeden iş adamlarının yaptırdığı yerler. Belediyemiz geliri olan bir belediye değil. Devletin takviyesi lazım. Baraj göçü daha da hızlandırdı. Örneğin Cenne köyünden 30 hane Konya'ya göçtü. Bir cenaze, düğün olacak olsa kimse yok."

Yıllar önce Konya'ya göç eden dernek başkanı ise şöyle demektedir: “Ermenek'in değişmeyen bir nüfus yapısı var. 1926'da Ermenek nüfusu 6442 idi. Şimdi 11 bin civarı. Bunca zaman içinde fark ortada. Bunun sebebi göç. Konya'da 70-80 bin, Antalya'da 20-25 bin Ermenekli var. Büyük şehirlerdeki Ermenekliler, Ermenek'in önüne geçmiş. Barajla birliktede göç durmadı ama gidenlerin yerini köylüler dolduruyor. Çevre köylerden göç eden çok fazlalaştı barajdan sonra." İlçenin sosyal, kültürel açıdan da kısıtlı olarak görülmesi göçü kolaylaştırmaktadır. Barajın bu göçü durdurmada ise nasıl bir rol oynadığı konusunda ise olumlu bir işlevi olmadığı görülmektedir. Yapılan mülakatlar gösteriyor ki göç tam olarak durdu diyemeyiz ama belli bir süre Ermenek gençlerinin şehre göçünü en azından erteledi diyebiliriz. Onun dışında ise 
ilçe halkının büyük kısmı okuma eğilimi yüksek bir nüfus barındırmaktadır. Bu nedenle baraj göçü durdurmadı ama kısmı olarak ertelemiştir. Diğer yandan barajla birlikte göçler hızlanmıştır da diyebiliriz. Zira büyük miktarda para alan pek çok aile şehirlerden daire almış, Ermenek'e sık sık gidip gelmek suretiyle yerleşmiştir. Zorunlu göç ettirilen Çavuş köyü de dâhil olmak üzere diğer köylerden de şehirlere göç eden olmuştur.

\section{Tartışma ve Sonuç}

$\mathrm{Bu}$ araştırma, geleneksel yapıdan modernleşmeye doğru giden bir süreç yaşayan Ermenek ilçesinin yapılan ikinci, barajdan sonra ise birinci sosyolojik araştırması olmuştur. Daha önce 1960'lı yıllarda Bahattin Akşit Antalya köylerinde araştırma yaparken Ermenek kasabasında da araştırma yapmış bazı tespitlerde bulunmuştur. $\mathrm{Bu}$ araştırmayla birlikte de tekrar kasabanın nasıl bir değişim geçirdiğini görmemize yardımcı olmuştur. İlçe, geleneksel parametreleri barındırmakla birlikte modernleşme unsurlarını da kendisine katmayı kolay kabul etmektedir. Nitekim eğitim alanında okuma oranının yüksek olması bunda etkili olmaktadır. İlçe, ulaşım zorluğu sebebi ile değişimi yavaş ve belli aralıklarda yaşamaktadır. Sekiz yıldır yapılmakta olan Ermenek Barajı HES projesi dışarıdan bir değiştirici rol oynamış, baraj ise 2011 de sonlanmış, elektrik üretimine ise Ekim 2012' de geçmiştir. Ermenek ilçesi kalkınmada öncelikli yerler arasında yer almış, barajın da bu kalkınmayı sağlaması amaçlanmıştır. Araştırma boyunca da şu görülmüştür ki artık kırsal kalkınma sadece tarımsal nitelikler, önlemler taşımamaktadır. Tarımın yanında diğer sektörler devreye sokulmuş, farklı sektörlerden projelerle kalkınma amaçlanmıştır. Ermenek ilçesinde bugüne kadar yaşadığı en büyük, en hareketli değişim barajla olmuştur. Şimdiye kadar ilçenin tek kaynağı kömür ocağı olsa da ilçenin 3-4 ailesini zengin etmiştir. Sosyo-ekonomik açıdan dikkati çeken bir değişim yaşamamıştır. Barajla birlikte ise bireysel, bireyler arası, toplumsal, kültürel düzeylerinde değişim gözlemlenmiştir. İlçenin eskiden beri yaşadığ demografik değişim zaten mevcut olup barajla birlikte ise coğrafi değişkenlerde rol oynadığ1 görüldü. Toplumsal değişmenin dinamiği burada genelde insan-doğa özelde ise insan-insan ilişkileri olmuştur. Burada değişimin yönü ise yukarıdan gelmiştir. Yani devletin kalkınma amaçlı 
planladığı proje olan baraj yukarıdan gelen bir değişim rolündedir. Şimdiye kadar ilçenin en dikkat çekici özelliği, niceliksel değişim olan göçtür. Bu hala da devam etmektedir. Baraj göçü durdurmamış sadece bir süreliğine ertelemiştir. Baraj inşaatı ilçenin vasıfsız genç nüfusu için iş kaynağ 1 olmuştur. Yaklaşık sekiz sene süren baraj inşaatı bu süre zarfında yerli yabancı kişilere iş kaynağ üzere iki şirketle yapılan baraj Türkiye ile yabancı devlet arasındaki işçiişveren ilişkisini, işçinin çalışma şartlarını, işçinin güvenliği konularında farkları da göstermiştir. Resmi bayramlarda yabancı şirket tatil verirken Türk şirketi tatil vermemiş, çalışma saatleri yabancı şirkette sekiz saat iken Türk şirketi on iki saate varan çalışma süreleri vermiştir. Ayrıca yabancı şirketin sendikası da mevcuttur. Bu da gösteriyor ki Türkiye hala bu konuda tam olarak kendini yenileyememiş, işçinin hakkını, güvenliğini sağlayan ortamı sağlayamamıştır. Çavuş köyü dışında Ermenek içindekilerin ve Ermenek'ten yıllar önce göç edenlerin toprakları da baraj için dâhil olan topraklar arasındaydı. Toprakların analizi, varsa içindeki ağaçların cinsi, yaşı, türü, sayısı gibi kıstaslara bakılarak fiyatlar belirlenmiş, buna göre fiyat dağılımı yapılmıştır. Barajla birlikte Ermenek, topraklarını su ile değiştirmiştir. Zaten sonuç olarak en başta barajın görselliğinin insanlar üzerinde büyük etki bıraktığı görülüyor. Ama asıl değişim toprağın para ile olan değişimi olmuştur. Yani değişimin temeli ve başlangıcı insan-doğa arasındaki ilişkisindedir. İlçe su kaynakları bakımından zengin olup rahatça kullanmıştır. Serbestçe akmış, halk istediği gibi kullanmıştır. Fakat barajla birlikte su belli bir alana kapatılmış, yeni bir enerji kaynağı olarak üretime sunulmuştur. İlçenin Göksu nehri de barajla birlikte belli bir alana kapatılmış dolayısıyla eskiden köylünün kullandığı su artık devlet tarafından halkın dokundurulamazlığına girmiştir. Burada su devletin midir halkın mıdır sorusu gündeme gelmektedir. Ermenek halkına göre barajla birlikte su kısıtlanmıştır ve halktan çıkarılmıştır. Halk artık o suya dokunamayacaktır. Diğer yandan su Ermenek halkı için ihtiyaçken Ermenek dışındakiler için hak olarak görülmektedir. Bu da gösteriyor ki suyun bir hak olması gerekirken ihtiyaç gözüyle bakılması onu metalaştırmaktadır. Aynı durumda toprakta metalaşmıştır. Mülakat sorularından biri toprağın ne ifade ettiği idi. Özellikle Çavuş köyü toprağın bir gün gelip altın kadar kıymetli olacağını ifade etmişlerdi. Dünyada olduğu gibi Tür- 
kiye'de de toprakların azalması, köylülüğün bitmeye yüz tutması görülmektedir. Gün geçtikçe toprağın azalışı onun daha da kıymetlendirecek ve su gibi pahalılaşacak olması metalaşmasına sebep olacaktır. Enerji ihtiyacımızı belki dışarıdan sağlayabilme imkânına sahipken toprağı bir yerlerden sağlama, ithal etme gibi bir şey söz konusu olamayacaktır. Dünya da pek çok dernek, örgüt bunun için mücadele etse de sonuç pek fazla değişmemektedir. Sonuç olarak bütün bunlar üretimden çok tüketime dayalı bir tarımsal dönüşüme işaret etmektedir. Oysa kalkınma denilen planlarda tüketimden ziyade üretim amaçlanmaktadır. Kendi içerisindeki potansiyelleri keşfettiren ve bununla yaşam döngüsü sağlayan bir süreçtir. Fakat Ermenek ilçesinde böyle olmamıştır. Artık büyük oranda tüketime geçen ilçe kendi kendine yetebilen, kendi üreten bir ilçe olmaktan çıkmıştır. Son dönemde marketler açılmış küçük esnaf artık eski rolünü kaybetmiştir. İlçede büyük oranda yeşil alanın yok olması ayrıca olumsuz sonuçlarındandır. Doğa Derneğinin araştırmasına göre de Türkiye'de en tehlikeli beş barajdan biri Ermenek barajıdır. Günümüzde değişimi zorlayan sebepler en başta küresel rekabetin artmasıdır. Uluslararası entegrasyonun da buna eklenmesiyle kalkınma planları, anlaşmaları hazırlanmaktadır. Dünyada olduğu gibi Türkiye' de bu entegrasyon döneminden geçmekte, uluslararası şirketlerle anlaşmalar yapılmaktadır. Doğaya ait kaynaklar, toprak, su alınır satılır hale gelmiş bu da doğayı, tarımı metalaştırmıştır. Böylece Marx'ın "metabolik yarılma" diye bahsettiği durumu gerçekleştirmiştir. Hazırlanan projelerde anlaşılan şirketlerden biri yabanc1dır. Ermenek barajının anlaşması da yabancı şirketle yapılmış, baraj yabancı şirket ortaklığında bitirilmiştir. İlçe için yapılan kalkınma stratejisinde tarımsal yapı bitirilmiş, pazarlama piyasasında ilçenin kendi iç dinamikleri durmuştur. Başka meslek alanlarına kaymaları için yöneticiler tarafından telkinde bulunulmuştur. Çavuş köyünden göç eden kırsal nüfus kentte vasıfsız işlerde çalışmaya başlamış, işçiye dönüşmüştür. Bu durum köylülügün bitmek üzere olduğu tartışmalarına destekleyici bir örnektir. Ülkenin enerji ihtiyacı karşılanırken tarımda kayıp yaşanmaktadır. Bütün bunlar ise göç hareketini durdurmamış aksine daha da hızlandırmıştır. Köyün başka yere taşınması köylüyü orada tutamamış, genç kesimin şehre gitmesine neden olmuştur. Öncelikle iç göç hareketi hızlanmıştır. Önce köylerden Ermenek ilçesine göç yaşanmakta, Ermenek'ten de başta Karaman, Konya gibi şehirlere göç hareketi görülmektedir. Bölge 
Kalkınma Politikaları Göçe Engel Olabilir mi? KaramanErmenekilç̧eÖrneği

halkının kamulaştırma bedeli alması kente gitmesini cesaretlendirmiştir. Önceden de göç veren bir yer olan ilçe kalkınma politikası sonucu da aynı sorunu yaşamaya devam etmektedir. 


\title{
EXTENDED ABSTRACT
}

\section{Can Development Policies Prevent Migration? The Case of Ermenek Sub Province of Karaman}

\author{
İlknurEkizAtaşer \\ KTO Karatay University
}

Turkey has been experiencing a rapid change and transformation in terms of demographic, socio-economic, political and social structure not only in the urban but also rural areas. The post-1980 radical policies have been implemented both in the political and economic spheres, and integration to the global markets became the primary goal once neoliberal approaches dominated economic policies of states. Policy arrangements thus included the privatization of certain public services, build-operate-transfer models, foreign partnerships, and business activities with foreign companies. Since 2001, these trends are associated with the development policies. On the other hand, policies aiming at the increases levels of welfare at every region were designed and implemented with the expectation of stopping migration from rural to urban areas. Several projects are therefore implemented at the regional levels. Building of dams occupy a primary place among policies of regional development and dams were built in rural areas with sufficient water resources. In other words, "water" has become the basic dynamic for change. The building of a dam in Ermeneksub province is one of such policy implementations among many other localities in Turkey.

The central focus of this research is on Ermenek subprovince of Karaman. Çavuş village which has been submerged by the dam waters is also in Ermenek. The fieldwork has been conducted in three different locations, namely the Çavuş village, Ermenek, and Konya, in order to reflect the three dimensions focused in the research. In line with the purposes of the research, qualitative research methods are used in this research and I have conducted interviews composed of 24 questions. In some of the interviews, there were more than one interviewees, and focus-group interviews are conducted in Çavuş village. 
The sampling of the research includes individuals living in Ermenek sub province of Karaman, former residents of Çavuş village which has submerged by the dam lake, former residents of Ermenek who now live in Konya and are organized in a civic association. Total number of interviewees is eighteen. The interviewees are chosen from among individuals who have some kind of direct relation to the dam, whose lands are now under dam waters, whose court processes were still underway, who received expropriation payments from the DSI and individuals who closely witnessed these processes.

Very few members of the local population have opposed the building of the dam and existing opposition was scattered, thus leading to the lack of an organized resistance. The building of the dam is seen as a win in terms of energy supplies, but a net loss for Ermenek subprovince. In terms of agricultural losses, the major loss is experienced by the Çavuş village. The predominant economic activity of the village inhabitants was agriculture. The agricultural plots outside the villagers' lands are owned by the inhabitants if Ermenek and Konya. For these two groups, the loss of agricultural lands to the dam has not been as destructive as it was for the villagers. Therefore, the Ermenek Dam has a very different meaning for the Çavuş village inhabitants who were forced to leave in comparison to Ermenek inhabitants. Villagers who live in constant fear of losing their homes and land represent the primary victims of the dam. In addition, water flow through the river is highly controlled and the villagers depending on the river water represent the most adversely affected group. Ermenek inhabitants admit this by accepting that the limitations on water flow and usage primarily threatens the villagers' economic activities.

When first informed that their village will be submerged by the dam, those living in Çavuş village did not believe it and therefore did not seriously plan about moving. Village inhabitants were also disoriented in this case because a certain deadline for moving out from village was not announced. The option to scatter to nearby villages was not welcome by the village inhabitants.

People from Ermenek who live outside Ermenek tend to see the impact of the dam from two perspectives. They both acknowledge the geographical changes caused by the dam and the negative consequences caused by the submerging of Çavuş village. However, those living in Ermenek seem 
to know and care less about this second adverse impact in comparison to Ermenek-originated people living outside the subprovince.

Ermenek dam project was also a temporary employment opportunity for those living in Ermenek. It was a relatively better option when compared to working in coal mines in the region. Working in the dam construction provided especially younger people with a temporary income. On the other hand, objections to expropriation prices led to numerous court cases and even after the settlement of the cases, questions about the justice in expropriation prices continued. Consequently, the state had to pay high expropriation prices in general.

Another problem in addition to court processes has been the resettlement of the Çavuşvillage. The authorities did not determine the place and date of resettlement of the village, as well as how the actual moving will be organized. The villagers on the other hand, have been very reluctant to move. The village's relocation to a place where villagers would be able to continue their lives as they used to and thus satisfy them did not happen. Once the dam construction is finished and the dam started filling, authorities had to move the village hastily. Despite widespread media coverage of the incompetence in resettlement, the DSI continued to defend itself and possible attempts at finding a satisfactory solution to the problem were avoided.

With the expropriation, 2820 individuals living or possessing real estate in the region were entitled to receive expropriation payments. This corresponds to the record-high levels of expropriation payments in the history of the sub province. All the interviewees acknowledged that never in its past Ermenek has received such a large amount of money. The first visible result of this money flow has been in the increased sales of apartments and cars.Inhabitants living in other villages of Ermenek did not stay in their homes either and have migrated to different locations.

Although a growth in industry and service sectors might be expected, the interviewees have serious doubts about it. In the past, artisanship was more prevalent in Ermenek and unemployment was relatively low. With the mechanization of production, artisanship declined and unemployment rates increased. Because the region has been associated with high outwards migration, development should be a primary target to prevent 
migration especially after the expropriation payments. However, the actual result of developmental projects in the region seems to fail to fulfill this purpose. Especially the transportation issues pose a significant disadvantage for economic investments in Ermeneksub province.

On the other hand, the economic gains of the dam project for the inhabitants has resulted in changing patterns of migration within the village, sub province and city levels. While many of those formerly living in villages have migrated to Ermenek and to a lesser degree to provincial urban centers, some of those living in Ermenek have migrated to other provincial centers. The demographic transformation in Ermenek thus have changed the existing social and economic relations. Older inhabitants of Ermenek have developed a sensitivity towards the new inhabitants of the city and previous communal relations started to deteriorate. The existing social and cultural limitations in Ermenek have facilitated migration from here. In terms of stopping and reversing this migration, the dam remains to play no positive function. According to the interviews, the migrations from Ermenek did not completely finish, but the dam has slowed down the younger inhabitants' migration to larger cities. It should also be noted that the sub provincial population attributes high value on education. Therefore, we can argue that the dam has just postponed further migration rather than stopping it. For many other, migrating from Ermenek and its' villages have become a more attractive option because of the high expropriation payments. Many families have bought apartments in bigger cities, while retaining their communal and kinship relation in Ermenek by frequently visiting the subprovince. Many families from villages, including the forcibly evacuatedÇavuş village, have started a new life in big cities.

\section{Kaynakça / References}

Akşit, B. (1966). Türkiye'de az gelişmiş kapitalizm ve köylere girişi. Ankara: ODTÜ Öğrenci Birliği Yayınları

Bakırcı, M. (2007). Türkiye'de kırsal kalkınma: Kavramlar-politikalar-uygulamalar. Ankara: Nobel Yayınları.

Baudrillard, J. ( 1998). Üretimin aynası (Çev. O. Adanır). İzmir: Dokuz Eylül Yayınları 
Boran, B. S. (1945). Toplumsal yapı araştırmaları, Ankara: Ankara Üniversitesi Dil Tarih- Coğrafya Fakültesi Yayınları, Sosyoloji Serisi: 3.

Ekiz, İ. (2013). Kalkınma politikası olarak barajlar ve toplumsal değişim - Karaman-Ermenek örneği, II. Türkiye Lisansüstü Çalışmalar Kongresi, Bursa.

Ferry, L. (2000). Ekolojik yeni düzen. (Çev: T. Ilgaz). İstanbul: Yapı Kredi Yayınlar1.

Foster, J. B. (2001). Marx’ın ekolojisi: Materyalizm ve doğa (Çev: E. Özkaya). Ankara: Epos Yayınları

Geray, C. (2011). Dünden bugüne kırsal gelişme politikaları. Ankara: Phoenix Yayınevi

Güçbilmez, E. (1972). Yenimahalle Ve Kayadibi karşılaştırmalı bir köy araştırması. Sevinç Matbaası, Ankara: Ankara Üniversitesi Siyasal Bilgiler Fakültesi Yayınları no:327

Gülçubuk, B. ve Yıldırak, N. (1994, Kasım): Tarım kesiminde işsizliğin boyutları ve çözüm yolları I.Ulusal Sosyoloji Kongresinde sunulan bildiri, Dünyada Ve Türkiye'de Güncel Sosyolojik Gelişmeler, Ankara: Sosyoloji Derneği Yayınları III.

Gouverneur, J. (1997).Kapitalist ekonominin temelleri: Çă̆daş kapitalizmin Marksist ekonomik tahliline giriş (Çev. F. Başkay). Ankara: İmge Kitabevi.

Harvey, D. (2012). Sermaye muamması: Kapitalizmin krizleri (Çev. S. Savran). İstanbul: Sel Yayıncilık.

Ildırar, M. (2004). Bölgesel kalkınma ve gelişme stratejileri. Adana: Nobel Yayınlari.

Karpat, K. (2010). Türk demokrasi tarihi: Sosyal, kültürel, ekonomik temeller, İstanbul: Timaş Yayınları.

Kartal, F. (2009). Suyun metalaşması, suya erişim hakkı ve sosyal adalet.TMMOB Su Politikaları Kongresinde sunulmuş bildiri, 20.03.2013 tarihinde http://www.tmmob.org.tr/yayınlar/kitap_goster.php?kodu= 186 adresinden erişilmiştir.

Keyder, Ç ve Yenal, Z, (2013). Bildiğimiz tarımın sonu, küresel iktidar ve köylülük. İstanbul: İletişim Yayınları.

Polat, M. H. (2012). Küreselleşen kalkınma: Bir eleştiri, İstanbul: Açılım Yayınları.

Özensel, E. (2013 Ocak-Haziran) Taşranın yetim çocuğu: Kır. Sosyoloji Divanı, Dosya: Taşra Fragmanları. Konya: Çizgi Yayınevi. 
Öztürk, Ş. (2014). Yeni köy sosyolojisi tartışmaları: Küreselden yerele tarım politikaları ve yoksulluk. Doğu Kitabevi: İstanbul.

Yılmaz, G. (2009). Suyun metalaşması: Kıtlı̆̆ın Nedeni kıtlığa çare olabilir mi? İstanbul: Sosyal Araştırmalar Vakfi.

MEVKA [Mevlana Kalkınma Ajansı]. (2011). 2023 vizyon stratejileri Ermenek ilçe faaliyetleri raporu ve sonuçları, 21.02.2013 tarihinde www.mevka.org.tr adresinden erişildi.

Özbağdatlı, N. (2012,).Modern tufan: Barajlar.Doğa Derneği, 13.01 .2014 tarihinde http://www.dogadernegi.org/modern-tufan-barajlar.aspx adresinden erişildi.

Gazete İlanı İle Davalı Arıyorlar (Temmuz 31,2010). Sabah Gazetesi.26.01.2014 tarihine $\quad$ http://www.sabah.com.tr/Yasam/2010/07/31/gazete_ilani_ile_davali_ariyorlar, adresinden erişildi.

Su altında kalacak köylerini terk etmiyorlar (Mart 27,2009). Hürriyet Gazetesi. 26.01.2014 tarihinde http://arama.hurriyet.com.tr/arsivnews.aspx?id=11302646 adresinden erişildi.

\section{Kaynakça Bilgisi / Citation Information}

Ekiz-Ataşer, İ.(2019).Kalkınma politikaları göçe engel olabilir mi? KaramanErmenekilçeörneği. OPUS-Uluslararası Toplum Araştırmaları Dergisi, 14(20), 1936-1974. DOI: 10.26466/opus.595120 